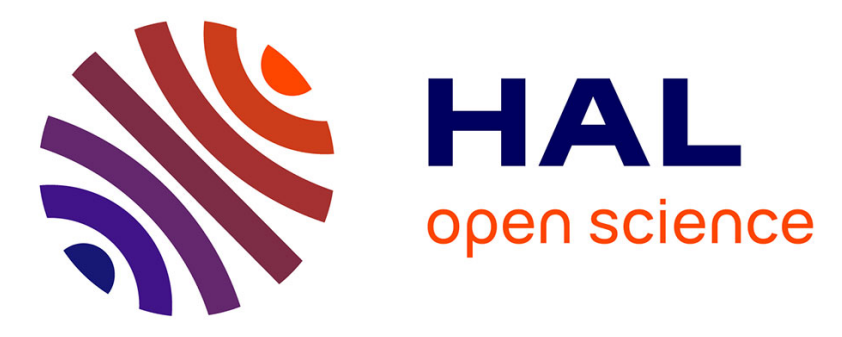

\title{
Synthetic Studies toward the Total Synthesis of Tautomycetin
}

\author{
Danilo Pereira de Sant'ana, Celso de Oliveira Rezende Júnior, Jean-Marc \\ Campagne, Luiz Carlos Dias, Renata Marcia de Figueiredo
}

\section{To cite this version:}

Danilo Pereira de Sant'ana, Celso de Oliveira Rezende Júnior, Jean-Marc Campagne, Luiz Carlos Dias, Renata Marcia de Figueiredo. Synthetic Studies toward the Total Synthesis of Tautomycetin. Journal of Organic Chemistry, 2019, 84 (19), pp.12344-12357. 10.1021/acs.joc.9b01712 . hal-02334465

\section{HAL Id: hal-02334465 \\ https://hal.umontpellier.fr/hal-02334465}

Submitted on 23 Nov 2020

HAL is a multi-disciplinary open access archive for the deposit and dissemination of scientific research documents, whether they are published or not. The documents may come from teaching and research institutions in France or abroad, or from public or private research centers.
L'archive ouverte pluridisciplinaire HAL, est destinée au dépôt et à la diffusion de documents scientifiques de niveau recherche, publiés ou non, émanant des établissements d'enseignement et de recherche français ou étrangers, des laboratoires publics ou privés. 


\title{
Synthetic Studies toward the Total Synthesis of Tautomycetin
}

\author{
Danilo Pereira de Sant’Ana, ${ }^{\dagger \ddagger}$ Celso de Oliveira Rezende Júnior, ${ }^{\dagger \ddagger}$ Jean-Marc Campagne, ${ }^{* \S}$ Luiz \\ Carlos Dias, ${ }^{* \dagger}$ and Renata Marcia de Figueiredo*§ \\ † Institute of Chemistry, University of Campinas, Campinas/São Paulo - 13083-970, Brazil. \\ \& Institut Charles Gerhardt, UMR 5253, Univ Montpellier, CNRS, ENSCM, 240 Avenue du Professeur Emile Jeanbrau, \\ 34296 Montpellier Cedex 5, France.
}
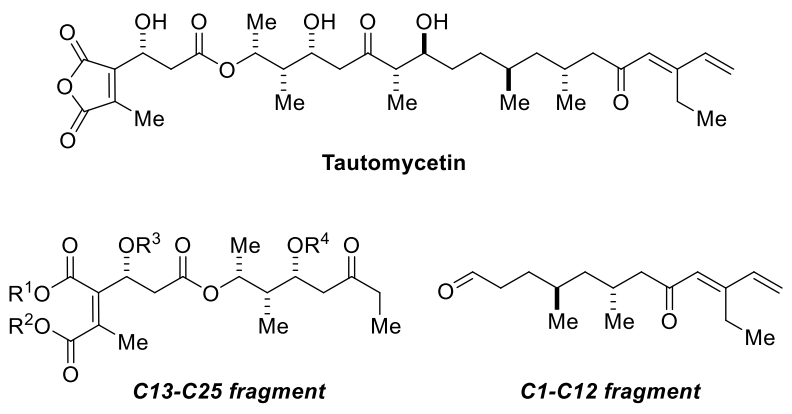

ABSTRACT: The studies culminating in the synthesis of two large subunits of tautomycetin are described. The first one, fragment $\mathrm{C}_{1}-\mathrm{C}_{12}$ that has an anti-1,3-dimethyl system and a terminal diene unit, was accomplished in 10 linear steps in $7.4 \%$ overall yield. The second one, fragment $\mathrm{C}_{13}-\mathrm{C}_{2} 5$ which bears the sensitive anhydride framework and the majority of the stereogenic centers, was prepared in 13 linear steps (longest sequence) in 8\% overall yield. Among the key transformations used, a regioselective epoxide opening, a Pd-catalyzed addition of terminal alkyne to acceptor alkyne, a Mukaiyama aldol reaction, a Yamaguchi esterification and a homemade mild di-esterification can be cited. The chosen strategies allowed good yields, stereoselectivity, reproducibility and scalability for several important intermediates.

\section{INTRODUCTION}

Tautomycetin (TTN, 1, Figure 1) is a natural linear polyketide isolated by Isono and co-workers in 1989 from extracts of Streptomyces griseochromogenes during a screening of soil microorganisms. ${ }^{1-3}$ Initially recognized as an antifungal antibiotic able to induce morphological changes on human erythroid leukemia cell $\mathrm{K}_{562}$ in the late 1980 s, ${ }^{4}$ follow-up studies revealed its inhibitory activity toward protein phosphatases type 1 and 2 ( $\mathrm{PP} 1$ and $\mathrm{PP} 2$ ). Compared to other natural products that share this biological activity [i.e. tautomycin (2), okadaic acid (3), forstriecin (4) and cantharidin (5), (Figure 1)], 5 TTN proved to be very specific toward $\mathrm{PP} .^{6}$ More recently, the potential of TTN against colorectal ${ }^{7}$ and breast $^{8}$ cancer cells growth as well as its activity as immunosuppressor in organ transplantation, ${ }^{9,10}$ have also been highlighted. ${ }^{11}$

Besides the impressive biological potential of TTN, this natural product has a unique and original chemical structure embedding eight stereogenic centers, ${ }^{12}$ a terminal diene motif, an anti-1,3-dimethyl system and an anhydride moiety that exists as an equilibrium mixture with its open diacid form in a 4:6 ratio in methanol-buffer solution. ${ }^{1,13}$

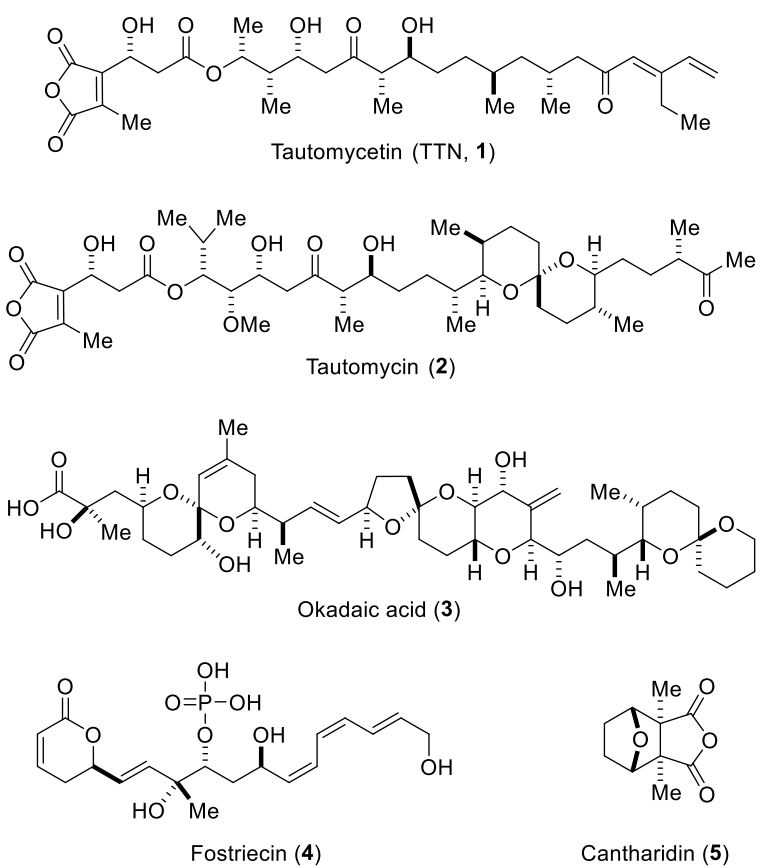

Figure 1. Tautomycetin (1) and selected examples of natural products that inhibit $\mathrm{PP}_{1}$ and $\mathrm{PP}_{2}$. 

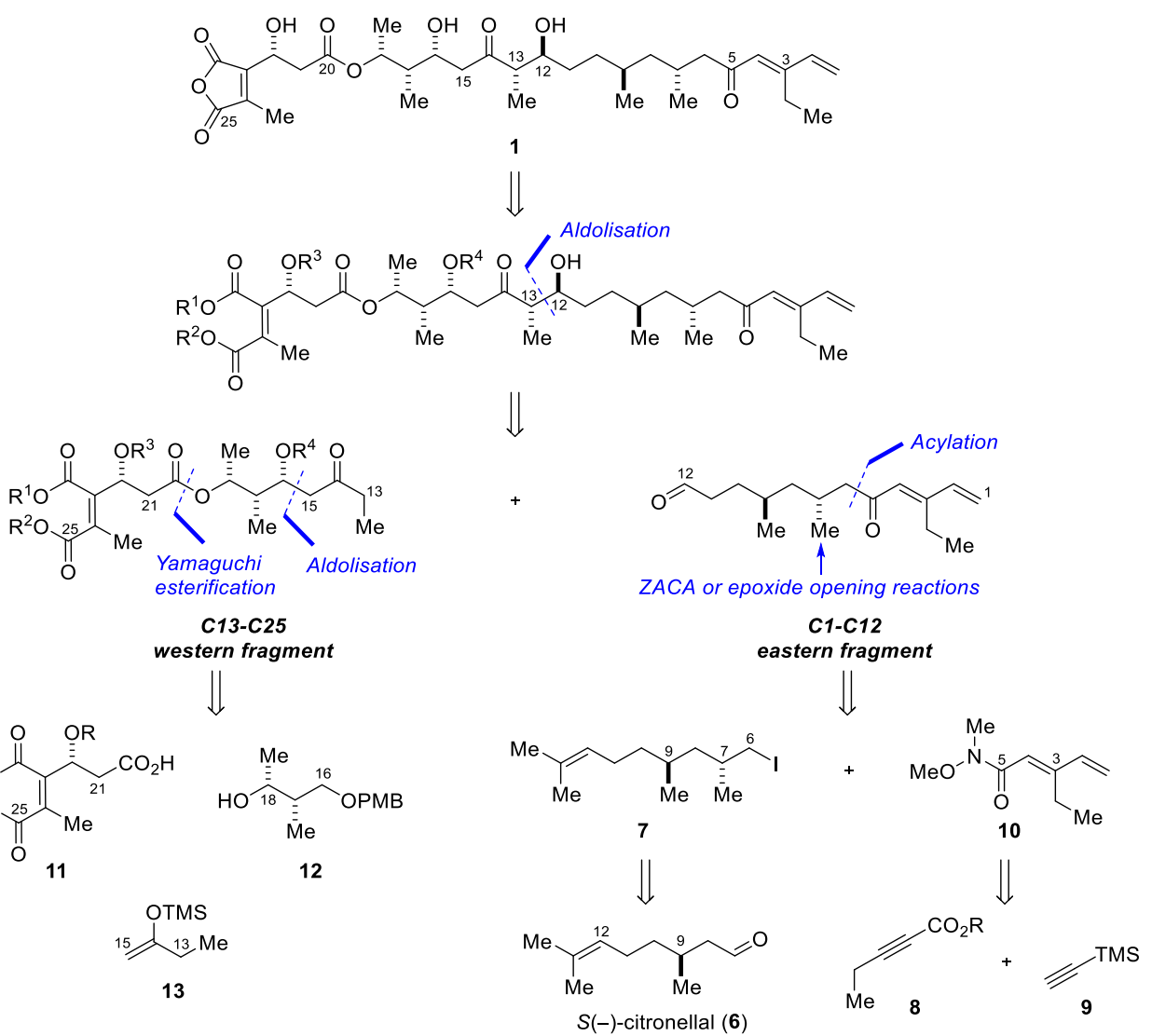

Scheme 1. Retrosynthesis of TTN. $\mathrm{R}^{1}, \mathrm{R}^{2}, \mathrm{R}^{3}, \mathrm{R}^{4}=$ protecting groups.

Due to the unique biological properties and structural complexity of TTN, we embarked into a program aimed at its total synthesis. Despite efforts devoted to this end by Oikawa and co-workers, ${ }^{14,15}$ a total synthesis of TTN has not yet been achieved. Herein, we report the synthesis of two fragments $\left(\mathrm{C}_{1}-\mathrm{C}_{12}\right.$ and $\left.\mathrm{C}_{13}-\mathrm{C}_{25}\right)$ and our synthetic efforts toward the assembly of the entire backbone of TTN.

The retrosynthetic strategy that we envisaged for accessing 1 is outlined in scheme 1 . A disconnection on $\mathrm{C}_{12}-\mathrm{C}_{13}$ bond gives two fragments of more or less the same size. The linear backbone of TTN would be thus obtained through a boron mediated aldolisation. At last, a final general deprotection step would afford the synthetic TTN. We anticipated that $\mathrm{C}_{1}-\mathrm{C}_{12}$ moiety, which bears an antidimethyl system, would be formed via acylation of an organolithium derivative in order to form $\mathrm{C}_{5}$-C6 bond. The regio- and stereocontrolled introduction of the methyl group in $C_{7}$ could derive either from a strategy based on the ZACA reaction or via a regioselective ring opening of an epoxide. The terminal diene system was to be formed by means of palladium-catalyzed addition of terminal alkyne to acceptor alkyne developed by Trost and co-workers. ${ }^{16}$ Elaboration of $\mathrm{C}_{13}-\mathrm{C}_{25}$ challenging segment, that bears the anhydride moiety, would be achieved by a sequence of reactions including a Mukaiyama aldol addition ( $\mathrm{C}_{15}-\mathrm{C}_{16}$ bond) and an esterification in the conditions of Yamaguchi (O19-C20 bond). The strategy pictured to reach the puzzling diester form of the dialkylmaleic anhydride moiety (segment $\mathbf{1 1}$ ) was envisaged from an original step of di-esterification, under very mild conditions, previously developed in our laboratories. ${ }^{17}$

\section{RESULTS AND DISCUSSION}

Synthesis of Fragment $\mathrm{C}_{1-C_{12}}$

On the basis of Negishi's work, ${ }^{18}$ known alcohol 15 was prepared in three steps from (S)-(-)-citronellal (6) in 30\% overall yield (Scheme 2). Thanks to a $\mathrm{Zr}$-catalyzed asymmetric carboalumination of alkene $\mathbf{1 4}$ (ZACA reaction), the anti-dimethyl system could be satisfactorily addressed. However, in our hands, this strategy appeared difficult to be reproduced on a multigram scale preserving the same outcomes in terms of both yield and selectivity. Therefore, a fallback method was envisaged.

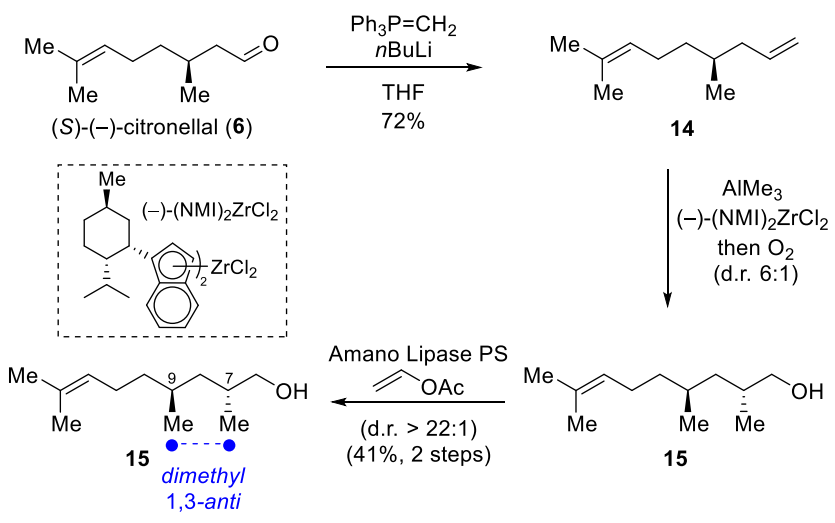

Scheme 2. Synthesis of the anti-1,3-dimethyl system via the ZACA reaction. ${ }^{18 a}$ 
The intermediate $\mathbf{1 5}$ could also be synthesized following the strategy described in scheme 3. The HornerWadsworth-Emmons (HWE) reaction on $\mathbf{6}$ followed by the ester reduction to the corresponding alcohol (DIBAL$\mathrm{H}$ at $-78{ }^{\circ} \mathrm{C}$ ), afforded the allylic alcohol 16 in $88 \%$ yield. Asymmetric epoxidation of 16 under Sharpless conditions $^{19}[(+)$-DIPT, Ti(OiPr) $4, t \mathrm{BuOOH}, 4 \AA \mathrm{AS},-35$ to -20 ${ }^{\circ} \mathrm{C}$ ] gave the epoxy alcohol 17 in $74 \%$ yield with a good diastereomeric ratio (d.r.) of 16:1. It might be mentioned that when the epoxidation was realized in the presence of less encumbered chiral ligand (+)-DEPT a better yield was observed $(81 \%)$ however with lower diastereoselectivity (d.r 4.5:1). With epoxy alcohol 17 in hands, the regio- and diastereoselective ring opening studies were thus undertaken. The goal here was to favor the formation of the 1,2diol 18, that bears the 1,3-anti dimethyl system, instead of the 1,3 regioisomer. Within this purpose, this step was tried with trimethylaluminium in different solvents. Indeed, in our hands, this key step showed to be quite sensitive to the solvent used on the reaction. While the reaction fails when $\mathrm{CH}_{2} \mathrm{Cl}_{2}$ was used, which is a quite common solvent for this kind of transformation, ${ }^{20}$ toluene gave moderate yield (55\%) and d.r. (6:1). Interestingly, changing toluene by pentane allowed us to improve both yield and diastereoselectivity (82\%, d.r. 13:1). Subsequent oxidative cleavage $\left(\mathrm{NaIO}_{4}\right)$ and reduction $\left(\mathrm{NaBH}_{4}\right)$ afforded the alcohol 15 in $79 \%$ yield. Following this strategy, 15 was obtained in five steps with improved overall yield $(42 \% \text { vs } 30 \%)^{21}$ and better scalability than the one described on scheme $2 .{ }^{22}$ Finally, iodide 7 was prepared by using the conditions devised by Garegg-Samuelsson (PPh3, I2, and Imidazole) in $84 \%$ yield. ${ }^{23}$

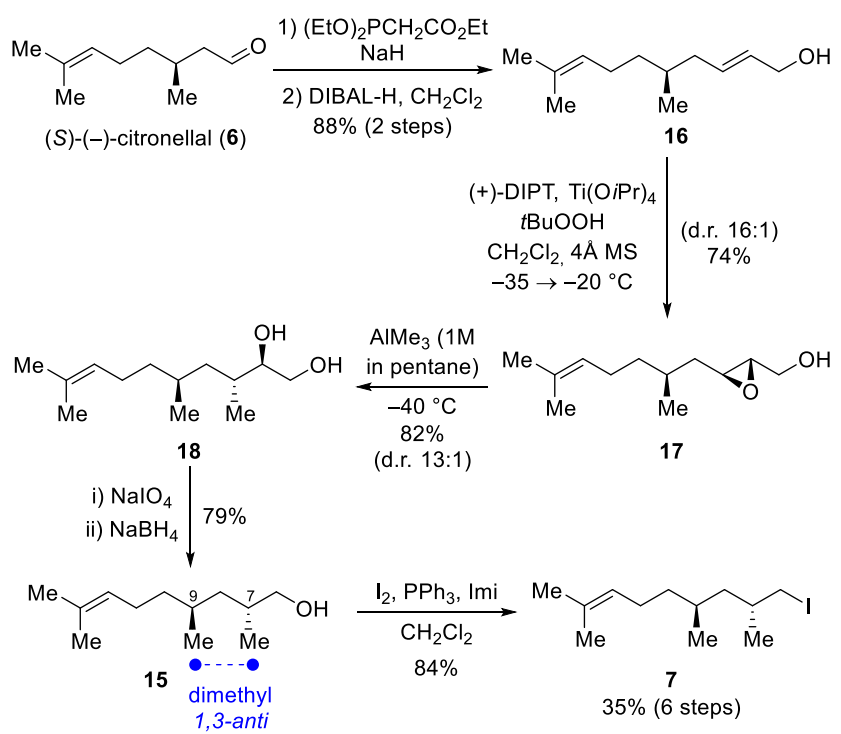

Scheme 3. Synthesis of the 1,3-dimethyl system via the epoxidation strategy.

Concerning the terminal diene moiety, a palladiumcatalyzed addition of terminal alkyne 9 to the acceptor alkyne $8[\mathrm{Pd}(\mathrm{OAc})$ 2, tris(2,6-dimethoxyphenyl)phosphine (TDMPP), THF] developed by Trost and co-workers ${ }^{16}$ enabled the isolation of adduct 19 in good yield (85\%) and excellent $E / Z$ ratio (>95:5) (Scheme 4 ). The $E$ geometry could be established by NOESY experiments after the reduction of the ester into the corresponding alcohol. Saponification of the ester function $(\mathrm{LiOH}$, $\mathrm{THF} / \mathrm{MeOH} / \mathrm{H}_{2} \mathrm{O}$ 5:1:1) and Weinreb amide formation (MeONHOMe.HCl, DCC, DMAP, $\mathrm{CH}_{2} \mathrm{Cl}_{2}$ ) allowed the access to the ene-yne intermediate 20 that afforded the diene-amide 10 (31\% overall yield for four steps) after reduction of the triple bond with the Lindlar catalyst.

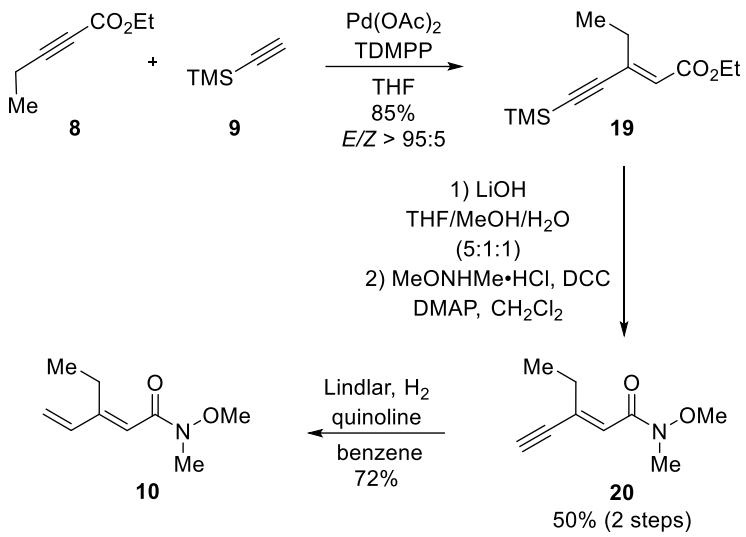

Scheme 4. Synthesis of amide 10 bearing the terminal diene system.

The stage was then set for the assembly of the backbone of the eastern fragment $\mathrm{C}_{1}-\mathrm{C}_{12}$ by the key acylation step via organolithium 21 (derived from $t \mathrm{BuLi}$ addition into iodide 7) addition to the Weinreb amide 1o. ${ }^{24}$ The transformation proceeded smoothly when conducted in Et2O at $-78{ }^{\circ} \mathrm{C}$ and the required coupling adduct 22 was obtained in $58 \%$ yield (Scheme 5). ${ }^{25}$ Next, the regio- and chemoselective oxidative cleavage of the more enriched double bond on the triene 22 afforded the fragment $\mathrm{C}_{1-12}$ in $36 \%$ yield for the two steps. The synthesis of subunit $\mathrm{C}_{1}-\mathrm{C}_{12}$, that embedded two among the eight stereocenters present in TTN and the dimethyl 1,3-anti system, was thus achieved in 10 linear steps from commercially available (S)-(-)-citronellal in $7.4 \%$ overall yield. ${ }^{26}$

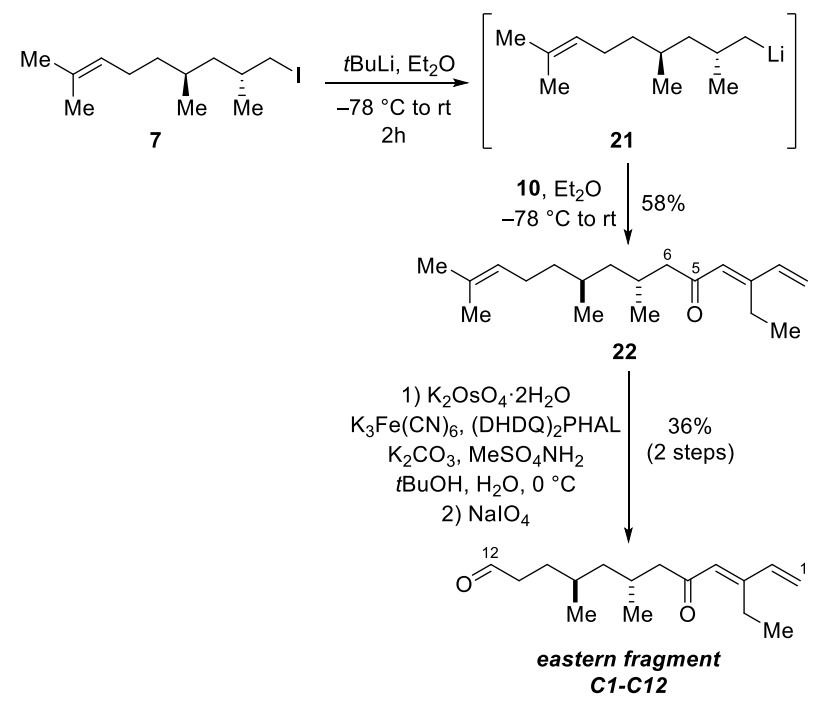

Scheme 5. Accomplishment of the synthesis of fragment $\mathrm{C}_{1-}$ C12. 


\section{Synthesis of Fragment $\mathrm{C}_{13}-\mathrm{C}_{25}$}

We have next initiated the studies toward the western fragment $\mathrm{C}_{13}-\mathrm{C}_{15}$ that bears the six other stereocenters and also the challenging anhydride moiety. Even though the preparation of the anhydride derivative seems to be straightforward, examples of syntheses reported in the literature showed that this is not the case due to the equilibrium between the anhydride and its opened diacid form (Scheme 6a). This point was indeed demonstrated during studies toward the total synthesis of tautomycin 2, a structural analog of TTN (see figure 1), that bears the same tricky 2,3-disubstituted maleic anhydride segment. Isono and co-workers reported in 1993 the synthesis of the segment 26 (16\% overall yield, 11 steps from 23 and 24 ) (Scheme 6b), ${ }^{27}$ and two years later, Oikawa, Ichiara and co-workers described the synthesis of compound $\mathbf{2 8}$ (13\% overall yield, 13 steps from 27) (Scheme 6c). ${ }^{13 a}$

a) Equilibrium between anhydride and diacid forms:

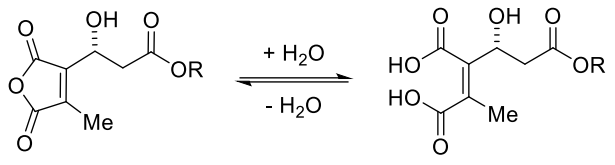

b) Synthesis of Dialkylmaleic anhydride by Isobe and co-workers:

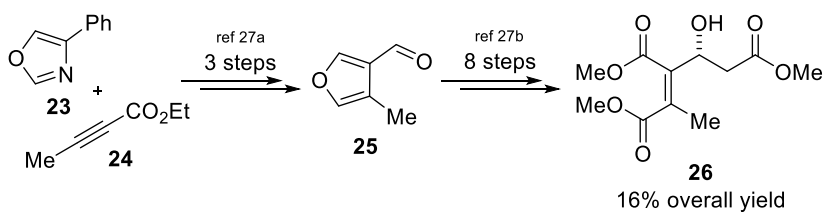

c) Synthesis of Dialkylmaleic anhydride by Oikawa, Ichiara and co-workers:

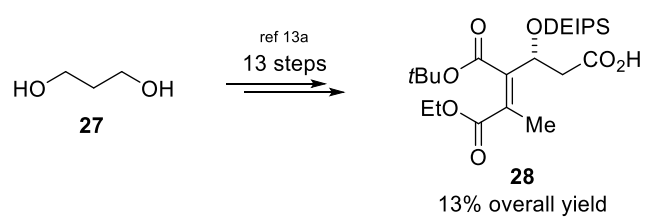

Scheme 6. a) Chemical behavior in aqueous media: equilibrium between anhydride and diacid forms. b) Synthesis of the dialkylmaleic anhydride 26 by Isono and co-workers. c) Synthesis of the dialkylmaleic anhydride $\mathbf{2 8}$ by Oikawa, Ichiara and co-workers. DEIPS = Diethylisopropylsilyl.

Considering this behavior, and keeping in mind the possible synthetic problems that this equilibrium can accommodate, we therefore envisaged a synthetic strategy where the anhydride was to be formed only in the last step of the synthesis [i.e. during the final deprotection of all protecting groups once the entire carbon backbone of the TTN has been built (see scheme 1)]. We envisioned the synthesis of the dialkylmaleic anhydride intermediate 11 starting from the commercially available dimethyl 2butynedioate 29 (Scheme 7). By using the stereoselective addition of an organocopper reagent $(\mathrm{MeCuLiCN}),{ }^{28}$ followed by the trapping of the transiently formed $\beta$ disubstituted- $\alpha$-carbethoxyvinyl)cuprate with $3 \mathbf{3 0}^{13 \mathrm{~b}}$ the unsaturated ketone intermediate 31 was isolated in $58 \%$ yield in several grams scale. With $\mathbf{3 1}$ in hands, we under-

took studies toward the enantioselective reduction of the ketone function. For this purpose, we first chose the Corey-Bakshi-Shibata (CBS) conditions which are broadly used in total syntheses. ${ }^{29}$ Under these conditions (CBS catalyst, $\mathrm{BH}_{3} \cdot \mathrm{BMS}$ in $\mathrm{THF}$ at $\mathrm{o}{ }^{\circ} \mathrm{C}$ ) the expected alcohol could be isolated in a moderate yield of $40 \%$ and a disappointing enantiomeric ratio (e.r. 6o:40). We were able to improve both yield and enantioselectivity by simply moving to (+)-Ipc2 $\mathrm{BCl}$ at $-2 \mathrm{O}^{\circ} \mathrm{C}$ for which alcohol 32 could be isolated in $70 \%$ yield with an e.r. of 86:14..$^{\circ}$ The configuration of the newly generated $C_{22}$ stereogenic center was confirmed via Mosher ester analysis (see supporting information for details). ${ }^{31}$ Silylation of 32 (TBSOTf, 2,6lutidine, $\mathrm{o}^{\circ} \mathrm{C}$ ) gave rise to the silylether 33 in $94 \%$ yield.
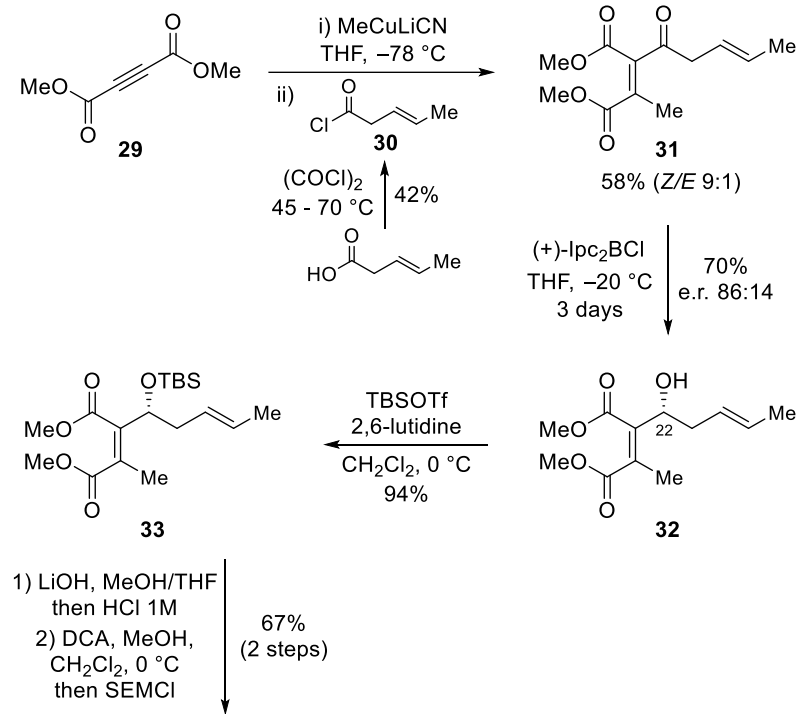

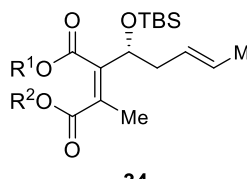

34

$\mathrm{R}^{1}=\mathrm{Me}, \mathrm{R}^{2}=\mathrm{SEM}$

$R^{1}=S E M, R^{2}=M e$
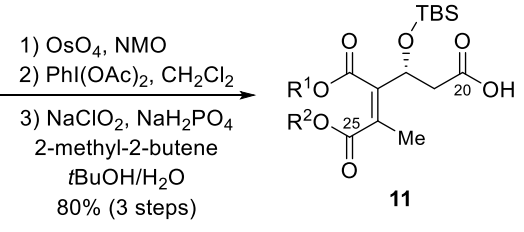

Scheme 7. Synthesis of $\mathrm{C}_{20} \mathrm{O}-\mathrm{C}_{2} 5$ moiety.

Aware of the difficulties encountered on precedent works toward the anhydride moiety synthesis, ${ }^{13 a, 27}$ we have anticipated that the key for a robust strategy lies on an easy ester deprotection at the end of the synthesis. Therefore, a great deal of efforts and work were devoted to find a practical and mild methodology to form the strategic dialkylmaleic anhydride intermediate 34. Indeed, among the weaknesses highlighted on previous strategies, the need for harsh conditions that are not always compatible with the polyfunctionalized structure of TTN or difficulties to find orthogonal protecting groups for the diester intermediate synthesis hamper the accomplishment of the total synthesis of $\mathbf{1} .{ }^{14,15}$ Thus, to overcome all this potential future complications, we relied on a mild and practical procedure for the esterification of free carboxylic acids with $\beta$-(trimethylsilyl)ethoxymethyl chloride developed in our laboratories. ${ }^{17}$ Accordingly, an anhydride 
intermediate was formed through the saponification of 33 $\left(\mathrm{LiOH}, \mathrm{THF} / \mathrm{H}_{2} \mathrm{O}, \mathrm{rt}\right)$, then sequential bis-esterification (DCA, $\mathrm{MeOH}$ at $\mathrm{o}^{\circ} \mathrm{C}$ then SEMCl) led to di-ester 34 in $67 \%$ yield ( 2 steps). The use of such silyl/alkyl-ester derivative 34 has the advantage to allow a single late deprotection step of all silyl-protecting groups in the molecule under mild conditions avoiding strong basic conditions. Then, $\mathbf{3 4}$ was transformed into acid $\mathbf{1 1}$ by oxidative cleavage of the double bond $\left[\mathrm{OsO}_{4}, \mathrm{NMO}\right.$, acetone $/ \mathrm{H}_{2} \mathrm{O}$ then $\mathrm{PhI}(\mathrm{OAc})_{2}$ in $\mathrm{CH}_{2} \mathrm{Cl}_{2}$ ] followed by oxidation under Pinnick's conditions ( $80 \%$ over 3 steps). ${ }^{32}$

The synthesis of alcohol $\mathbf{1 2}$ commenced with the protection of (S)-Roche ester (35) in the presence of 4methoxybenzyl trichloroacetimidate to form the $p$ methoxybenzyl (PMB) ether 36 (Scheme 8). DIBAL-H mediated reduction into alcohol 37 followed by Swern oxidation ${ }^{33}$ provided aldehyde 38 in $71 \%$ yield for these three steps. In order to avoid both decomposition and $\mathrm{C}_{17}$ racemization, alcohol 37 was oxidized into aldehyde 38 prior to the step of methylation and directly used without further purification. Then, treatment of $\mathbf{3 8}$ with Gilman's reagent ${ }^{34}(\mathrm{Me} 2 \mathrm{CuLi})$ in $\mathrm{Et}_{2} \mathrm{O}$ at low temperature afforded the secondary alcohol $\mathbf{1 2}$ in good yield $(75 \%)$ and diastereomeric ratio (12:1). The stereochemistry of the newly formed hydroxy group was established on the basis of NOE interactions between vicinal protons of the corresponding $p$-metoxybenzylidene acetal derivative 39.35 The sequence proposed to reach $\mathbf{1 2}$ works finely; it can be scaled up easily and all intermediates are very stable (with the exception of aldehyde $\mathbf{3 8}$ ).

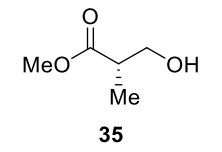

(S)-Roche ester

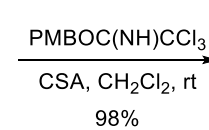

$98 \%$

$$
\begin{aligned}
& \text { DIBA } \\
& \mathrm{DSO} \\
& \mathrm{Cl}_{2} \\
& \hline
\end{aligned}
$$

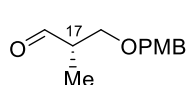

38
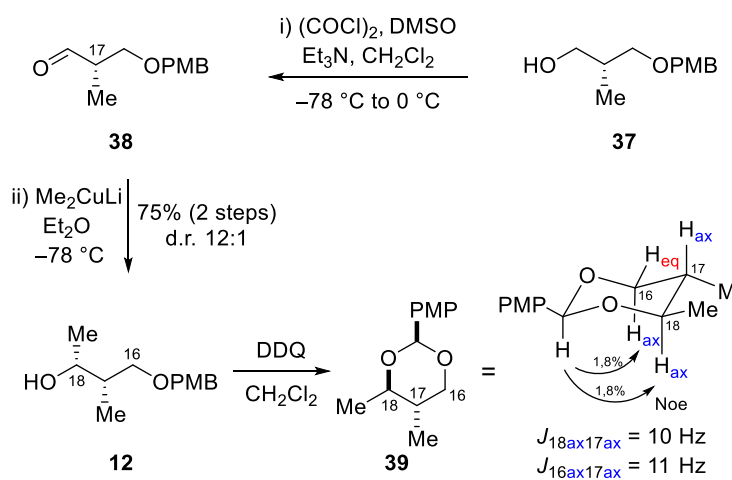

37

12$$
39
$$

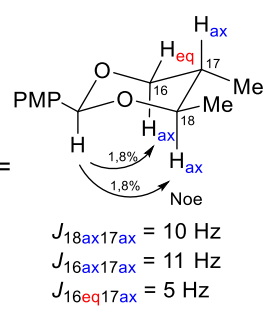

Scheme 8. Synthesis of secondary alcohol 12.

Having synthesized the acid $\mathbf{1 1}$ and the secondary alcohol 12, the coupling step was investigated (Scheme 9). Of the various esterification protocols that were examined, Yamaguchi's reagent (2,4,6-trichlorobenzoyl chloride 40) proved the most fruitful, giving ester $\mathbf{4 1}$ in excellent $91 \%$ yield. ${ }^{36}$ Removal of the PMB group from 41 using DDQ furnished the primary alcohol $\mathbf{4 2}$ in $85 \%$ yield.

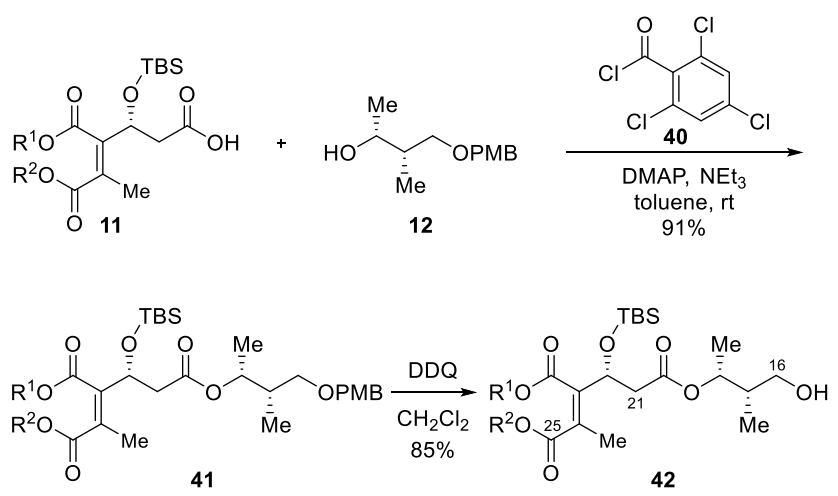

Scheme 9. Synthesis of primary alcohol $\mathbf{4 2}$.

Prior to the oxidation of $\mathbf{4 2}$ into aldehyde and its use in the Mukaiyama aldol reaction with 13, we studied this transformation on the model compound 45. Starting from alcohol 12 (see scheme 8 ), model aldehyde 45 was synthesized in three steps via O-benzoylation (92\%), PMB removal (83\%) followed by Swern oxidation (Scheme 10). Exposure of $\mathbf{4 5}$ to 2-(trimethylsilyloxy)-1-butene $\mathbf{1 3}$ (easily prepared from butanone 46 in $41 \%$ yield) in the presence of $\mathrm{BF}_{3} \cdot \mathrm{Et}_{2} \mathrm{O}$ in $\mathrm{Et}_{2} \mathrm{O}$ at $-78^{\circ} \mathrm{C}$ furnished the aldol adduct 47 in $42 \%$ yield (two steps; oxidation/aldolisation) and a diastereomeric ratio of 4:1. The relative configuration of the newly formed stereocenter was established by conversion of $\mathbf{4 7}$ into ketal $\mathbf{4 8}$, under $\mathrm{Ba}(\mathrm{OH})_{2}$ treatment, and NOESY experiment. We could thus define a trans relative stereochemistry for $\mathrm{C}_{18}, \mathrm{C}_{17}$ and $\mathrm{C}_{1} 6$ for ketal 48 . Accordingly, the relative configuration of $\mathrm{C}_{17}$ and $\mathrm{C}_{16}$ on 47 is syn, and as the absolute stereochemistry of $\mathrm{C}_{17}$ is known $(S)$, the one from the newly formed stereocenter is $(R)$. Although we expected a better selectivity, this result is consistent with a Felkin/1,3-anti aldol adduct as an antirelationship between the $\alpha$ - and $\beta$-substituents influences the facial bias of the carbonyl moiety under non-chelating conditions. ${ }^{37}$

On the basis of these encouraging model studies, the aldol condensation was thus investigated on our real substrate (Scheme 11). For this purpose, the oxidation of alcohol 42 (Scheme 7) furnished the required aldehyde 49. Then, we were delighted to obtain the expected aldol adduct 50 in $50 \%$ yield (two steps; Swern oxidation and aldolisation) and a similar 4:1 diastereomeric ratio. Next, we proceeded with the TBS protection step of alcohol $\mathbf{5 0}$. Although this transformation generally works well, in our case it proved to be more difficult than anticipated. Indeed, under the classical conditions (TBSOTf and 2,6lutidine) the protection failed. By tuning the amounts of reagents (excess of TBSOTf) resulted extensive degradation of $\mathbf{5 0}$. We believe that the reluctance of this substrate toward TBS protection might be due to the easy dehydration on $\mathrm{C}_{15}-\mathrm{C}_{16}$ under mild basic conditions as observed by Isono and co-workers. ${ }^{2}$ Moving to milder conditions (TBSCl and imidazole in DMF) only provided the unchanged substrate 50. To circumvent this problem, we decided to add a less encumbered TMS protecting group. 
Gratefully, the TMS protection works finely in the presence of $\mathrm{N}$-trimethylsilylimidazole in $\mathrm{CH}_{2} \mathrm{Cl}_{2}$ at room temperature (quantitative yield). This step concluded thus a sequence of 13 linear steps to provide the western

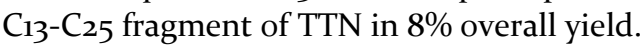
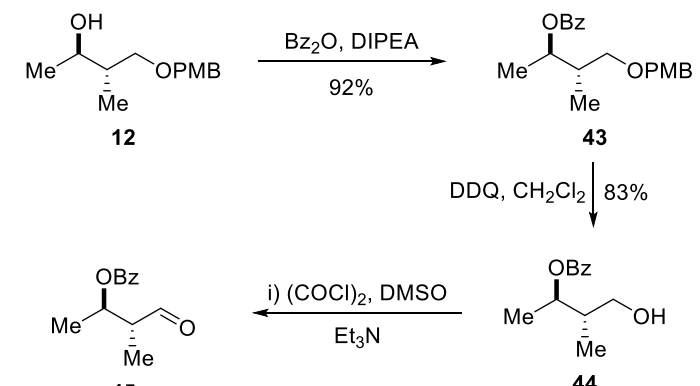

44
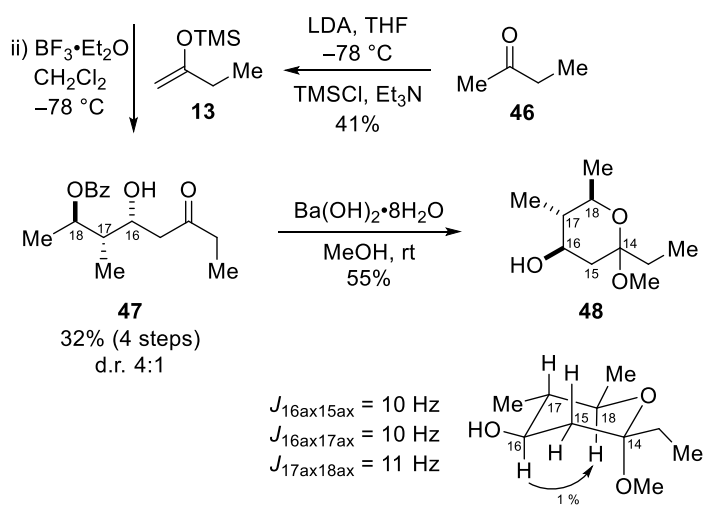

Scheme 10. Survey of the aldol reaction on the model aldehyde 45 .

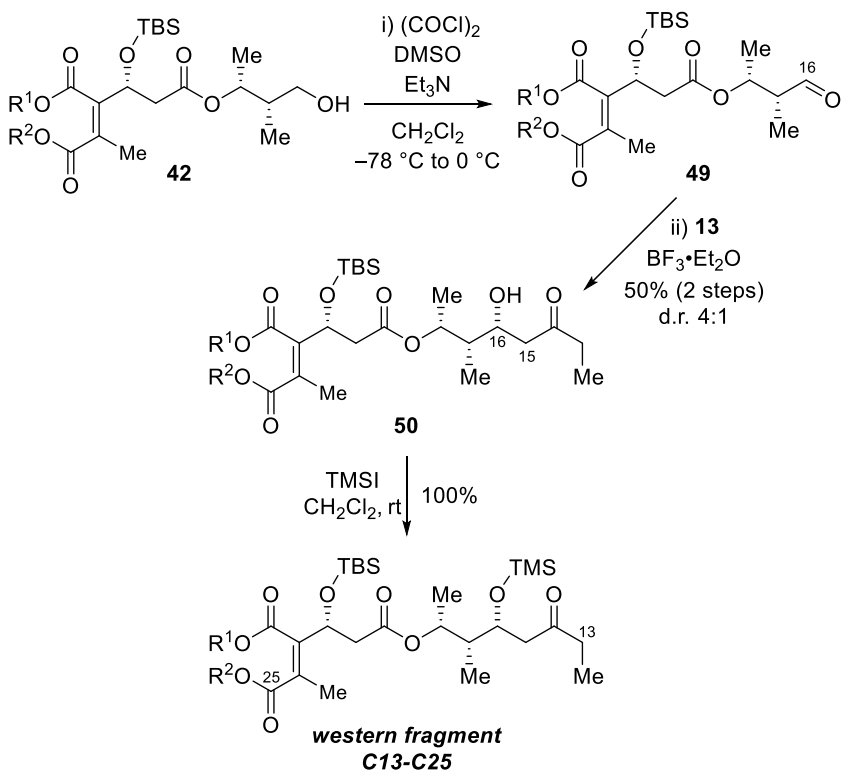

Scheme 11. Assembly of the carbon backbone of the protected fragment $\mathrm{C}_{13}-\mathrm{C}_{25}$ via Mukaiyama's aldolisation. TMSI = $\mathrm{N}$-Trimethylsilylimidazole.

\section{Endgame strategy toward the TTN synthesis}

With main fragments $\mathrm{C}_{1}-\mathrm{C}_{12}$ and $\mathrm{C}_{13}-\mathrm{C}_{25}$ of TTN synthetized, we were ready to proceed with their attachment in order to build the entire backbone of TTN. To remind, the endgame steps of our proposed strategy (see Scheme 1) relied on a key boron-mediated aldolisation to forge and control the relative stereochemistry of $\mathrm{C}_{12}-\mathrm{C}_{13}$ bond ${ }^{38}$ followed by a final removal of all protecting groups. Knowing that 1,2-anti adducts are mostly like to be obtained via E-boron enolates, 39 we tried the condensation by pre-mixing fragment $\mathrm{C}_{13}-\mathrm{C}_{25}$ with (cHex) ${ }_{2} \mathrm{BCl}$ (which favors $\mathrm{E}$-enolate formation) in the presence of $\mathrm{Et}_{3} \mathrm{~N}$ in $\mathrm{Et}_{2} \mathrm{O}$ at $-30{ }^{\circ} \mathrm{C}$ followed by the addition of aldehyde $\mathrm{C}_{1-}$ $\mathrm{C}_{12}$ at $-78{ }^{\circ} \mathrm{C}$ (Scheme 12). The usually recommended oxidative quench was avoided due to the presence of double bonds on both fragments which are prone to oxidation. Then, the crude material of the aldol reaction was engaged in the final deprotection step in the presence of $\mathrm{HF}$ in $\mathrm{CH}_{3} \mathrm{CN}$. Even though we got some evidence concerning the formation of TTN (a mass spectra of the crude material and an HPLC profile, see supporting information), $4^{\circ}$ to our greatest regret, we were unable to purify and isolate the natural product. We probably encountered problems associated with the high instability of the natural product as described in the original papers (i.e. sites both prone to reduction and oxidation, the possible degradation via retro-aldol reactions and the quite unpredictable behavior of the anhydride moiety).
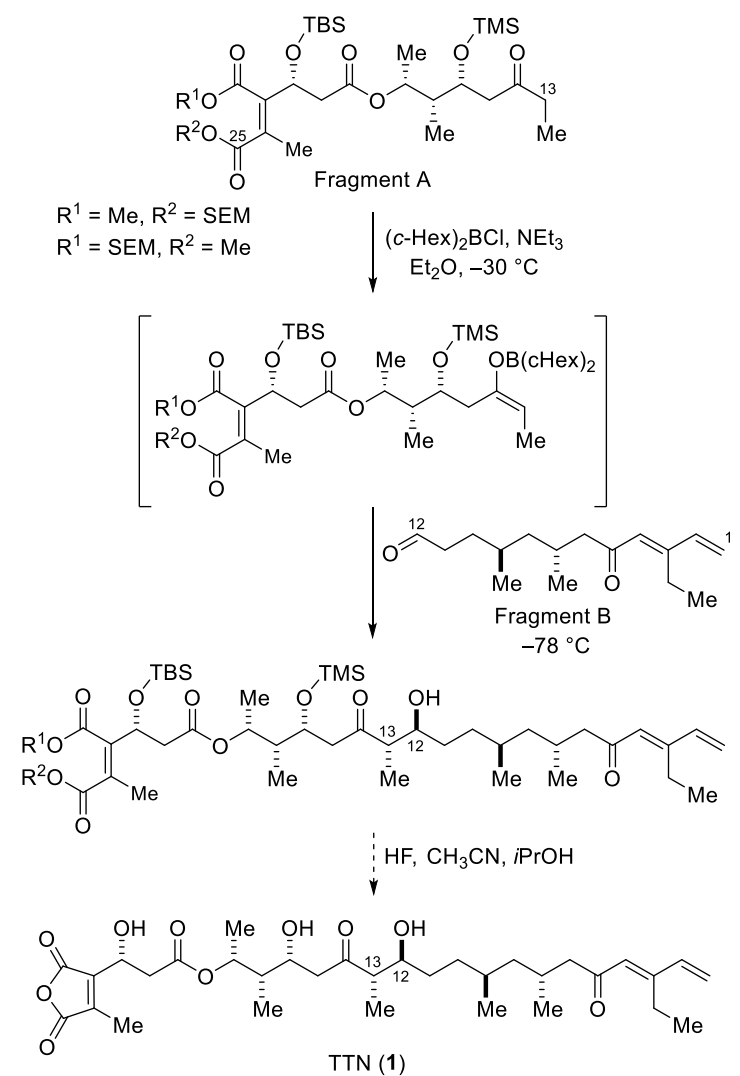

Scheme 12. Studies toward the completion of the TTN total synthesis.

\section{CONCLUSION}

We have described the synthesis of two advanced fragments of tautomycetin (TTN, 1): the eastern one $\left(\mathrm{C}_{1}-\mathrm{C}_{12}\right.$ segment, 10 linear steps; $7.4 \%$ yield) which bears both the terminal conjugated diene and the anti-1,3-dimethyl sys- 
tem and the western one $\left(\mathrm{C}_{13}-\mathrm{C}_{25}\right.$ segment, 13 linear steps; $8 \%$ overall yield) that includes four from the eight stereogenic centers present in the molecule and the tricky anhydride framework. Besides the remarkable and vast biological properties of this natural linear polyketide, its unique chemical structure displays a real challenge for chemical synthesis. Likewise, the very sensitive chemical nature of TTN in addition to its low natural availability were responsible for a late complete stereochemistry characterization..$^{12}$ Thus, to the best of our knowledge, no total synthesis of this natural product has been described so far. During our work on the endgame strategy to conclude the total synthesis, indications concerning the formation of TTN were obtained; regrettably, all attempts to purify and isolate the natural product failed in our hands. The difficulties faced might be related to the chemical instability previously observed for this compound. ${ }^{12}$ Nonetheless, the synthesis of two large subunits of TTN was accomplished in good overall yields and stereocontrols. The strategies used allowed high reproducibility and easy scale-up of key intermediates and the challenging dialkylmaleic anhydride moiety could be efficiently prepared through a homemade method.

\section{EXPERIMENTAL SECTION}

4.1. General Method. Unless otherwise specified (see paragraph below), all commercial products and reagents were used as purchased, without further purification. Reactions were carried out in round-bottom flasks, and Schlenk tubes were equipped with a magnetic stirring bar under argon atmosphere. All reactions were carried out under an atmosphere of argon with dry solvents under anhydrous conditions unless otherwise stated. Analytical thin-layer chromatography (TLC) of all reactions was performed on silica gel 60 F254 TLC plates. Visualization of the developed chromatogram was performed by UV absorbance (254 nm), using $p$ anisaldehyde, $\mathrm{KMnO}_{4}$, vanillin or phosphomolybdic acid stains. Flash chromatography was carried out on silica gel 60 $\AA$ (35-70 nm). FT-IR spectra were recorded with a PerkinElmer Spectrum 10oo; absorptions are given in wave numbers $(\mathrm{cm}-1)$. ${ }^{1} \mathrm{H}(250,400,500$ and $600 \mathrm{MHz})$ and ${ }^{13} \mathrm{C}(62.5$, 10o, 125 and $150 \mathrm{MHz}$ ) NMR spectra were recorded with a Bruker 250, 400, 500 and Ultra Shield 400 Plus. ${ }^{1} \mathrm{H}$ chemical shifts are reported in delta $(\delta)$ units in parts per million (ppm) relative to the singlet at $7.26 \mathrm{ppm}$ for chloroform-d (residual $\mathrm{CHCl}_{3}$ ). ${ }^{13} \mathrm{C}$ chemical shifts are reported in $\mathrm{ppm}$ relative to the central line of the triplet at 77.o ppm for chloroform-d. Splitting patterns are designated as s, singlet; d, doublet; t, triplet; q, quartet; quint, quintet; $\mathrm{m}$, multiplet; l, large; and combinations thereof. All coupling constants $(J$ values) are reported in hertz $(\mathrm{Hz})$. Data are reported as follows: chemical shift ( $\delta$ in ppm), multiplicity, coupling constants $(\mathrm{Hz})$, integration, and attribution. Optical rotations were measured with a Bellingham + Stanley ADP 440 polarimeter or a PerkinElmer polarimeter with a sodium lamp at $589 \mathrm{~nm}$. Low resolution mass spectra were recorded on a Waters QTof-I and LTQ FT (Thermo Scientific, Bremen, Germany), spectrometer using electrospray ionization and electron ionization. High-resolution mass spectra were obtained using the mass spectrometers operated by the "Laboratoire de Mesures Physiques of the University of Mont- pellier" and Unicamp. THF was dried by distillation over sodium metal and benzophenone under argon. Dichloromethane $\left(\mathrm{CH}_{2} \mathrm{Cl}_{2}\right)$, triethylamine $\left(\mathrm{Et}_{3} \mathrm{~N}\right)$, 2,6-lutidine, toluene and diethyl ether $\left(\mathrm{Et}_{2} \mathrm{O}\right)$ were dried by distillation over $\mathrm{CaH}_{2}$ under argon. Methanol (MeOH) was distilled from $\mathrm{Mg}(\mathrm{OMe})_{2}$.

4.1.1. (S)-4,8-Dimethylnona-1,7-diene (14):18a To a solution of methyltriphenylphosphine bromide $(22.1 \mathrm{~g}, 64.3 \mathrm{mmol})$ in THF (81.0 mL) was added 1.6 M nBuLi (40.2 mL, 64.3 mmol) at $0^{\circ} \mathrm{C}$. After $30 \mathrm{~min}$ at $\mathrm{o}^{\circ} \mathrm{C}$, a solution of $(S)$-citronellal (5.00 $\mathrm{g}, 32.7 \mathrm{mmol})$ in THF $(50.0 \mathrm{~mL})$ was added. The reaction mixture was stirred for $3.5 \mathrm{~h}$ at $0^{\circ} \mathrm{C}$ and quenched by a saturated aqueous solution of $\mathrm{NH}_{4} \mathrm{Cl}(50.0 \mathrm{~mL})$. This mixture was extracted with $\mathrm{Et}_{2} \mathrm{O}(3 \times 25.0 \mathrm{~mL})$. The combined organic extract were dried over $\mathrm{MgSO}_{4}$, filtered and concentrated under reduced pressure. The crude was purified by flash chromatography, eluting with 95:5 hexane: $\mathrm{Et}_{2} \mathrm{O}$ to give $3.12 \mathrm{~g}$ of $\mathbf{1 4}$ ( $72 \%$ yield).

$\mathbf{R f}=0.88$ (hexane: $\mathrm{Et}_{2} \mathrm{O}$ 99:1). $[\alpha]_{\mathrm{D}}^{25}=-2.0\left(\right.$ c 1.2, $\left.\mathrm{CHCl}_{3}\right) .{ }^{1} \mathbf{H}$ NMR (250 MHz, $\left.\mathbf{C D C l}_{3}\right) \delta 5.79(\mathrm{~m}, 1 \mathrm{H}), 5.15-5.05(\mathrm{~m}, 1 \mathrm{H})$, $5.01(\mathrm{dd}, J 5.4,1.2 \mathrm{~Hz}, 1 \mathrm{H}), 4.96(\mathrm{~s}, 1 \mathrm{H}), 2.15-1.81(\mathrm{~m}, 4 \mathrm{H}), 1.68$ $(\mathrm{s}, 3 \mathrm{H}), 1.61(\mathrm{~s}, 3 \mathrm{H}), 1.53-1.47(\mathrm{~m}, 1 \mathrm{H}), 1.42-1.25(\mathrm{~m}, 1 \mathrm{H}), 1.23$ - $1.06(\mathrm{~m}, 1 \mathrm{H}), 0.88(\mathrm{~d}, J 6.6 \mathrm{~Hz}, 3 \mathrm{H}) .{ }^{13} \mathbf{C}\left\{{ }^{1} \mathrm{H}\right\}$ NMR $(\mathbf{6 2 . 5}$ MHz, $\left.\mathrm{CDCl}_{3}\right) \delta$ 137.7, 131.1, 124.9, 115.5, 41.4, 36.6, 32.4, 25.7, 25.6, 19.3, 17.6. IR (Film) 3076, 2966, 2914, 2874, 2854, 1641 $\mathrm{cm}^{-1}$.

4.1.2. (2R,4S)-2,4,8-Trimethylnon-7-en-1-ol (15) (method scheme 2):18a To a solution of $\mathrm{AlMe}_{3}(1.8 \mathrm{o} \mathrm{mL}, 18.6 \mathrm{mmol})$ and (-)-bis[(1-neomenthyl)indenyl]zirconium dichloride (250 mg, $0.37 \mathrm{mmol})$ in $\mathrm{CH}_{2} \mathrm{Cl}_{2}(18.0 \mathrm{~mL})$ was added a solution of the olefin $14(1.42 \mathrm{~g}, 9.30 \mathrm{mmol})$ in $\mathrm{CH}_{2} \mathrm{Cl}_{2}$ at room temperature. The reaction was stirred for $18 \mathrm{~h}$ at this temperature. Then, the mixture was cooled to $0^{\circ} \mathrm{C}$ and an intense flow of $\mathrm{O}_{2}$ was bubbled into the solution for $1.5 \mathrm{~h}$. The reaction was maintained under an $\mathrm{O}_{2}$ atmosphere at room temperature for $5 \mathrm{~h}$ and quenched by the addition of a solution of $\mathrm{HCl}(0.5 \mathrm{M}$, $15.0 \mathrm{~mL}$ ). The layers were separated and the aqueous layer was extracted with $\mathrm{CH}_{2} \mathrm{Cl}_{2}(2 \times 10.0 \mathrm{~mL})$. The organic extract was dried over $\mathrm{MgSO}_{4}$, filtered and concentrated under reduced pressure. The residue was purified by flash chromatography using 8o:20 hexane:EtOAc as eluent to provide 1.13 $\mathrm{g}$ of 15 in $66 \%$ yield and 6:1 d.r.

$1.10 \mathrm{~g}$ of this material $(6.02 \mathrm{mmol})$ was solubilized in $\mathrm{CH}_{2} \mathrm{Cl}_{2}$ (20.0 mL). Then, Amano Lipase PS (18o mg, $30.0 \mathrm{mg} / \mathrm{mmol}$ ) and vinyl acetate $(2.80 \mathrm{~mL}, 30.1 \mathrm{mmol})$ were added. The reaction was stirred for $3 \mathrm{~h}$. The mixture was filtered on Celite $^{\oplus}$, the solvent was evaporated and the crude was purified by flash chromatography on silica gel eluting with hexane:EtOAc 8o:20 to give $684 \mathrm{mg}$ of $\mathbf{1 5}$ in $44 \%$ yield from $\mathbf{1 4}$ and d.r. 22:1.

$\mathbf{R f}=0.57$ (hexane:EtOAc 80:20). $[\alpha]_{\mathrm{D}}^{25}=+23.0\left(\right.$ ( $\left.1.3, \mathrm{CHCl}_{3}\right)$. ${ }^{1} \mathrm{H}$ NMR $\left(500 \mathrm{MHz}, \mathrm{CDCl}_{3}\right) \delta_{5.09}(\mathrm{t}, J 7.0 \mathrm{~Hz}, \mathrm{iH}), 3.47(\mathrm{dd}, J$ $10.4,5.8 \mathrm{~Hz}, 1 \mathrm{H}), 3.39$ (dd, J 10.4, $6.6 \mathrm{~Hz}, 1 \mathrm{H}), 2.0-1.9(\mathrm{~m}$, $2 \mathrm{H}), 1.78-1.63(\mathrm{~m}, 4 \mathrm{H}), 1.6 \mathrm{o}(\mathrm{s}, 3 \mathrm{H}), 1.56-1.43(\mathrm{~m}, 2 \mathrm{H}), 1.37-$ $1.00(\mathrm{~m}, 4 \mathrm{H}), 0.88(\mathrm{~d}, J 6.7 \mathrm{~Hz}, 3 \mathrm{H}), 0.85(\mathrm{~d}, J 6.5 \mathrm{~Hz}, 3 \mathrm{H})$. ${ }_{13} \mathrm{C}\{1 \mathbf{H}\}$ NMR (125 MHz, $\left.\mathrm{CDCl}_{3}\right) \delta$ 131.1, 124.9, 69.1, 40.5, 38.0, 33.2, 29.6, 25.7, 25.5, 19.3, 17.7, 16.3. IR (Film) 3340 (broad), 2962, 2914, 2874, 2872, 2853, 1454, $1377 \mathrm{~cm}^{-1}$.

4.1.3. (S,E)-5,9-Dimethyldeca-2,8-dien-1-ol (16)

4.1.3.a. To a suspension of $\mathrm{NaH}$ ( $60 \%$ mass/mass) $(1.58 \mathrm{~g}, 39.6$ $\mathrm{mmol}$ ) in THF (112 $\mathrm{mL}$ ) was added triethyl phosphonoacetate (8.0o $\mathrm{mL}, 39.6 \mathrm{mmol})$ dropwise at $\mathrm{o}^{\circ} \mathrm{C}$. The suspension was 
stirred for $30 \mathrm{~min}$ at this temperature. A solution of $(S)$ citronellal $(4.70 \mathrm{~g}, 30.5 \mathrm{mmol})$ in THF $(51.0 \mathrm{~mL})$ was added dropwise and the mixture was stirred at this temperature for $1 \mathrm{~h}$. The temperature was allowed to reach room temperature and the reaction was stirred for an additional $18 \mathrm{~h}$. A saturated aqueous solution of $\mathrm{NH}_{4} \mathrm{Cl}$ was added $(100 \mathrm{~mL})$, the layers were separated, and the aqueous layer was extracted with $\mathrm{CH}_{2} \mathrm{Cl}_{2}(2 \times 50.0 \mathrm{~mL})$. The organic extract was dried with $\mathrm{Na}_{2} \mathrm{SO}_{4}$, filtered and concentrated under reduced pressure. The residue was purified by flash chromatography, eluting with 95:5 hexane:EtOAc to give $6.20 \mathrm{~g}$ of ethyl ester, $90 \%$ yield.

$\mathbf{R f}=$ o.50 (hexane:EtOAc 95:5). $[\alpha]_{\mathrm{D}}^{25}=-\mathbf{2 . 0}\left(\right.$ c 1.3; $\left.\mathrm{CHCl}_{3}\right) .{ }^{\mathbf{1}} \mathbf{H}$ NMR (25o MHz, $\left.\mathbf{C D C l}_{3}\right) \delta 6.93(\mathrm{dt}, J 15.4,7.5 \mathrm{~Hz}, 1 \mathrm{H}), 5.8(\mathrm{~d}$, J $15.4 \mathrm{~Hz}, 1 \mathrm{H}), 5.07(\mathrm{~m}, 1 \mathrm{H}), 4.17(\mathrm{q}, J 7.2 \mathrm{~Hz}, 2 \mathrm{H}), 2.21(\mathrm{~m}, 1 \mathrm{H})$, $2.00\left(\mathrm{~m},{ }_{3} \mathrm{H}\right), 1.67(\mathrm{~s}, 3 \mathrm{H}), 1.60\left(\mathrm{~m},{ }_{1} \mathrm{H}\right), 1.59\left(\mathrm{~s},{ }_{3} \mathrm{H}\right), 1.37(\mathrm{~m}$, $1 \mathrm{H}), 1.29(\mathrm{t}, J 7.2 \mathrm{~Hz}, 3 \mathrm{H}), 1.17(\mathrm{~m}, 1 \mathrm{H}), 0.89\left(\mathrm{~d}, J 6.7 \mathrm{~Hz},{ }_{3} \mathrm{H}\right)$. ${ }^{13 C}\left\{{ }^{1} \mathrm{H}\right\}$ NMR (62.5 $\left.\mathbf{M H z}, \mathbf{C D C l}_{3}\right) \delta$ 166.6, 148.1, 131.4, 124.4, 122.4, 60.0, 39.6, 36.6, 32.0, 25.6, 25.4, 19.4, 17.6, 14.2. IR (Film) 2964, 2915, 2874, 2854, $1722 \mathrm{~cm}^{-1}$. HRMS (ESI+) $\mathrm{m} / \mathrm{z}$ calculated for $\mathrm{C}_{14} \mathrm{H}_{25} \mathrm{O}_{2}[\mathrm{M}+\mathrm{H}]^{+} \mathbf{2 2 5 . 1 8 5 5}$, found 225.1964.

4.1.3.b. ${ }^{41}$ To a solution of the ethyl ester intermediate $(6.12 \mathrm{~g}$, $27.3 \mathrm{mmol})$ in $\mathrm{CH}_{2} \mathrm{Cl}_{2}(270 \mathrm{~mL})$ was added $1 \mathrm{M}$ DIBAL-H (65.0 $\mathrm{mL}, 65.0 \mathrm{mmol}$ ) dropwise at $-78^{\circ} \mathrm{C}$ (DIBAL-H solution was prepared immediately before use). After stirring at -78 ${ }^{\circ} \mathrm{C}$ for $2 \mathrm{~h}, \mathrm{MeOH}(50.0 \mathrm{~mL})$ and a solution of potassium tartrate $(220 \mathrm{~mL})$ were added and the mixture was stirred for $18 \mathrm{~h}$. The layers were separated and the aqueous layer was extracted with EtOAc ( 3 x 50.0 mL). The organic layer was dried with $\mathrm{Na}_{2} \mathrm{SO}_{4}$, filtered and concentrated under reduced pressure. The residue was purified by flash chromatography using hexane:EtOAc 70:30 as eluent to provide 4.90 $\mathrm{g}$ of $\mathbf{1 6}$, $98 \%$ yield.

$\mathbf{R f}=0.45$ (hexane:EtOAc 8o:20). ${ }^{\mathbf{H}} \mathbf{H}$ NMR (250 $\mathbf{M H z}, \mathbf{C D C l}_{3}$ ) $\delta_{5.71}-5.61(\mathrm{~m}, 2 \mathrm{H}), 5.09(\mathrm{dd}, J 7.7,6.5 \mathrm{~Hz}, 1 \mathrm{H}), 4.09(\mathrm{~d}, J 4.3$ $\mathrm{Hz}, 2 \mathrm{H}), 2.14-1.80(\mathrm{~m}, 4 \mathrm{H}), 1.68(\mathrm{~s}, 3 \mathrm{H}), 1.60\left(\mathrm{~s},{ }_{3} \mathrm{H}\right), 1.54-$ $1.44(\mathrm{~m}, 1 \mathrm{H}), 1.41-1.24(\mathrm{~m}, 2 \mathrm{H}), 1.23-1.05(\mathrm{~m}, 1 \mathrm{H}), 0.88(\mathrm{~d}, J$ $\left.6.6 \mathrm{~Hz},{ }_{3} \mathrm{H}\right) .{ }^{13} \mathrm{C}\left\{{ }^{1} \mathrm{H}\right\}$ NMR (62.5 $\left.\mathbf{M H z}, \mathrm{CDCl}_{3}\right) \delta$ 131.9, 131.2, 130.1, 124.7, 63.8, 39.6, 36.6, 32.5, 25.7, 25.5, 19.3, 17.6. IR (Film) 3377 (broad), 3016, 2964, 2914, 2874, 2856, 1456, 1439, $1377,1215 \mathrm{~cm}^{-1}$.

4.1.4. $\quad((2 S, 3 S)-3-((S)-2,6-D i m e t h y l e p-5-e n y l)$ oxiran-2-yl $)$ methanol (17): To a suspension of L-(+)-DIPT (3.90 mL, 19.0 mmol), MS $4 \AA$ (3.50 g) in $\mathrm{CH}_{2} \mathrm{Cl}_{2}$ (6o.o mL) was added $\mathrm{Ti}(i \mathrm{OPr})_{4}(6.04 \mathrm{~mL}, 20.0 \mathrm{mmol})$ at $-35^{\circ} \mathrm{C}$ and the mixture was stirred for $20 \mathrm{~min}$. $t \mathrm{BuOOH}(8.40 \mathrm{~mL}, 41.8 \mathrm{mmol})$ was added and the suspension was stirred for another $40 \mathrm{~min}$ at $-35^{\circ} \mathrm{C}$. A solution of alcohol $16(3.47 \mathrm{~g}, 19.0 \mathrm{mmol})$ in $\mathrm{CH}_{2} \mathrm{Cl}_{2}$ (35.0 $\mathrm{mL}$ ) was added dropwise. The suspension was left in the freezer at approximately $-20^{\circ} \mathrm{C}$ for $18 \mathrm{~h}$. Then, the mixture was filtered on Celite ${ }^{\circledR}$ and eluted with $\mathrm{CH}_{2} \mathrm{Cl}_{2}$. To this solution was added a solution of potassium sodium tartrate (100 $\mathrm{mL}$ ) and the mixture was stirred for $18 \mathrm{~h}$. The layers were separated, and the aqueous layer was extracted with $\mathrm{CH}_{2} \mathrm{Cl}_{2}(2 \times 100 \mathrm{~mL})$. The organic extract was dried with $\mathrm{Na}_{2} \mathrm{SO}_{4}$, filtered and concentrated under reduced pressure. The residue was purified by flash chromatography on silica gel, eluting with hexane:EtOAc (70:30) to provide $2.79 \mathrm{~g}$ of 17, $74 \%$ yield.

Rf $=0.54$ (hexane:EtOAc, 6o:40). $[\alpha]_{\mathrm{D}}^{25}=-19.0\left(\right.$ ( $\left.1.3, \mathrm{CHCl}_{3}\right)$. 'H NMR (250 MHz, $\left.\mathbf{C D C l}_{3}\right) \delta 5.14-4.97\left(\mathrm{~m},{ }_{1} \mathrm{H}\right), 3.90(\mathrm{~d}, J$ $12.4 \mathrm{~Hz}, 1 \mathrm{H}), 3.7 \mathrm{O}-3.5 \mathrm{O}\left(\mathrm{m},{ }_{1} \mathrm{H}\right), 3.01-2.92\left(\mathrm{~m},{ }_{1} \mathrm{H}\right), 2.89-$ $2.85(\mathrm{~m}, 1 \mathrm{H}), 2.06-1.92(\mathrm{~m}, 3 \mathrm{H}), 1.67(\mathrm{~s}, 4 \mathrm{H}), 1.59\left(\mathrm{~s},{ }_{3} \mathrm{H}\right), 1.56$ - $1.30(\mathrm{~m}, 3 \mathrm{H}), 1.26-1.15(\mathrm{~m}, 1 \mathrm{H}), 0.97(\mathrm{~d}, J 6.5 \mathrm{~Hz}, 3 \mathrm{H})$. $\left.{ }_{13 C} \mathbf{1} \mathbf{H}\right\}$ NMR (62.5 $\left.\mathrm{MHz}, \mathrm{CDCl}_{3}\right) \delta$ 131.4, 124.4, 61.6, 58.4, 54.8, 38.8, 36.8, 31.0, 25.7, 25.4, 19.9, 17.6. IR (Film) 3418 (broad), 2964, 2918, 2872, 2856, 1454, $1379 \mathrm{~cm}^{-1}$. HRMS (ESI+) $\mathrm{m} / \mathrm{z}$ calculated for $\mathrm{C}_{12} \mathrm{H}_{23} \mathrm{O}_{2}[\mathrm{M}+\mathrm{H}]^{+} 199.1698$, found 199.1699.

4.1.5. $\left(2 R,{ }_{3} R,{ }_{5} S\right)-3,5,9$-Trimethyldec-8-ene-1,2-diol (18): To a solution of the epoxide $17(3.90 \mathrm{~g}, 19.7 \mathrm{mmol})$ in hexane (100 $\mathrm{mL}$ ) was added dropwise a freshly prepared solution of $\mathrm{AlMe}_{3}(5.66 \mathrm{~mL}, 59.0 \mathrm{mmol})$ in hexane $(30.0 \mathrm{~mL})$ at $-40^{\circ} \mathrm{C}$. The reaction was stirred for $1 \mathrm{~h}$ at $-40^{\circ} \mathrm{C}$, then a saturated aqueous solution of $\mathrm{NH}_{4} \mathrm{Cl}(10.0 \mathrm{~mL})$ was added. The cold bath was removed, and a concentrated solution of sodium potassium tartrate was added $(50.0 \mathrm{~mL})$. The obtained mixture was stirred for $4 \mathrm{~h}$. The layers were separated, and the organic extract was washed with a saturated aqueous $\mathrm{NaCl}$ solution (100 $\mathrm{mL}$ ). The organic layer was thus extracted with EtOAc $(3 \times 50.0 \mathrm{~mL})$. The organic extract was dried with $\mathrm{Na}_{2} \mathrm{SO}_{4}$, filtered and concentrated under reduced pressure. The resulting residue was purified by flash chromatography, eluting with hexane:EtOAc (70:30). After purification, $3.65 \mathrm{~g}$ of 18 was obtained, $86 \%$ yield.

$\mathbf{R f}=0.46$ (hexane:EtOAc 6o:40). $[\alpha]_{\mathrm{D}}^{25}=+20\left(c\right.$ o.86, $\left.\mathrm{CHCl}_{3}\right)$. ${ }^{1} \mathrm{H}$ NMR (6oo MHz, $\mathbf{C D C l}_{3}$ ) $\delta_{5.12-5.10}(\mathrm{~m}, \mathbf{1 H}), 3.73(\mathrm{dd}, J$ 10.9, $\left.2.2 \mathrm{~Hz},{ }_{1} \mathrm{H}\right), 3.57(\mathrm{dd}, J 10.8,8.4 \mathrm{~Hz}, 1 \mathrm{H}), 3.54-3.48(\mathrm{~m}$, $\left.{ }_{1 \mathrm{H}}\right), 2.90(\mathrm{~s}, 1 \mathrm{H}), 2.82(\mathrm{~s}, 1 \mathrm{H}), 2.04-1.96(\mathrm{~m}, 2 \mathrm{H}), 1.73-1.66(\mathrm{~m}$, $\left.{ }_{4} \mathrm{H}\right), 1.62\left(\mathrm{~s},{ }_{3} \mathrm{H}\right), 1.55-1.47(\mathrm{~m}, 1 \mathrm{H}), 1.34-1.13\left(\mathrm{~m},{ }_{4} \mathrm{H}\right), 0.95-$ $0.84(\mathrm{~m}, 6 \mathrm{H}) .{ }^{13} \mathrm{C}\left\{{ }^{1} \mathrm{H}\right\}$ NMR (62.5 $\left.\mathbf{M H z}, \mathbf{C D C l}_{3}\right) \delta$ 131.1, 124.8, $76.8,64.5,39.6,38.3,33.6,29.6,25.7,25.6,18.9,17.6,15.1$. IR (ATR) 3362 (broad), 296o, 2813, 2874, 1672, 1454, 1377, 1216 $\mathrm{cm}^{-1}$. HRMS (ESI+) $\mathrm{m} / \mathrm{z}$ calculated for $\mathrm{C}_{13} \mathrm{H}_{27} \mathrm{O}_{2}[\mathrm{M}+\mathrm{H}]^{+}$ 215.2011, found 215.1998 .

4.1.6. $(2 R, 4 S)-2,4,8$-Trimethylnon-7-en-1-ol (15) (method scheme 3): To a solution of the diol 18 (3.50 g, $16.4 \mathrm{mmol})$ in THF (131 mL) and water $(32.8 \mathrm{~mL})$ at room temperature was added $\mathrm{NaIO}_{4}$ (21.0 g, $98.0 \mathrm{mmol}$ ) in a single portion. The reaction was stirred for $5 \mathrm{~h}$ and quenched by the addition of a saturated aqueous $\mathrm{NaCl}$ solution $(150 \mathrm{~mL})$. The layers were separated, and the aqueous layer was extracted with $\mathrm{CH}_{2} \mathrm{Cl}_{2}$ (3 $x$ 6o.o mL). The organic layer was dried with $\mathrm{Na}_{2} \mathrm{SO}_{4}$, filtered and concentrated under reduced pressure. The resulting residue was used in the next step without further purification.

The material from the previous step was solubilized in methanol $(164 \mathrm{~mL})$ and cooled to $\mathrm{o}^{\circ} \mathrm{C}$. To this solution was added $\mathrm{NaBH}_{4}$ (0.93 g, $\left.24.5 \mathrm{mmol}\right)$ in small portions over 5 minutes. The reaction was stirred for $15 \mathrm{~min}$ when a $0.5 \mathrm{M}$ solution of citric acid (100 mL) and $\mathrm{CH}_{2} \mathrm{Cl}_{2}(50.0 \mathrm{~mL})$ was added. The layers were separated and the aqueous layer extracted with $\mathrm{CH}_{2} \mathrm{Cl}_{2}$ (3 x $50.0 \mathrm{~mL}$ ). The organic layer was dried with $\mathrm{Na}_{2} \mathrm{SO}_{4}$, filtered and concentrated under reduced pressure. The crude was purified by flash chromatography using hexane:EtOAc (80:20) as eluent. After purification, $2.64 \mathrm{~g}$ of 15 was isolated in $87 \%$ yield for the two steps.

$\mathbf{R f}=0.57$ (hexane:EtOAc 80:20). $[\alpha]_{\mathrm{D}}^{25}=+23.0\left(\mathrm{c} 1.3, \mathrm{CHCl}_{3}\right)$. ${ }^{1}$ H NMR $\left(500 \mathrm{MHz}, \mathbf{C D C l}_{3}\right) \delta 5.09(\mathrm{t}, J 7.0 \mathrm{~Hz}, \mathrm{iH}), 3.47(\mathrm{dd}, J$ 10.4, $5.8 \mathrm{~Hz}, 1 \mathrm{H}), 3.39(\mathrm{dd}, J 10.4,6.6 \mathrm{~Hz}, 1 \mathrm{H}), 2.0-1.9(\mathrm{~m}$, $2 \mathrm{H}), 1.78-1.63(\mathrm{~m}, 4 \mathrm{H}), 1.60(\mathrm{~s}, 3 \mathrm{H}), 1.56-1.43(\mathrm{~m}, 2 \mathrm{H}), 1.37-$ $1.00(\mathrm{~m}, 4 \mathrm{H}), 0.88\left(\mathrm{~d}, J 6.7 \mathrm{~Hz},{ }_{3} \mathrm{H}\right), 0.85\left(\mathrm{~d}, J 6.5 \mathrm{~Hz},{ }_{3} \mathrm{H}\right)$. ${ }^{13} \mathrm{C}\left\{{ }^{1} \mathrm{H}\right\}$ NMR (125 $\left.\mathrm{MHz} \mathrm{CDCl}_{3}\right) \delta$ 131.1, 124.9, 69.1, 40.5, 38.0, 
33.2, 29.6, 25.7, 25.5, 19.3, 17.7, 16.3. IR (Film) 3340 (broad), 2962, 2914, 2874, 2872, 2853, 1454, $1377 \mathrm{~cm}^{-1}$.

4.1.7. $(6 S, 8 R)-9$-Iodo-2,6,8-trimethylnon-2-ene (7): То а suspension of $\mathrm{PPh}_{3}(2.70 \mathrm{~g}, 10.3 \mathrm{mmol})$ and imidazole ( $0.76 \mathrm{~g}$, $11.2 \mathrm{mmol}$ ) in $\mathrm{CH}_{2} \mathrm{Cl}_{2}$ (10.0 mL) was added $\mathrm{I}_{2}(2.62 \mathrm{~g}, 10.3$ $\mathrm{mmol})$ at $\mathrm{o}^{\circ} \mathrm{C}$. After $10 \mathrm{~min}$ stirring the suspension became dark red, then a solution of alcohol $15(1.60 \mathrm{~g}, 8.60 \mathrm{mmol})$ in $\mathrm{CH}_{2} \mathrm{Cl}_{2}$ (7.00 $\left.\mathrm{mL}\right)$ was added and the reaction was stirred for $18 \mathrm{~h}$ at the room temperature. The reaction was concentrated under reduced pressure and the residue purified by flash chromatography using 99:1 hexane: $\mathrm{Et}_{2} \mathrm{O}$ as the eluent. After purification, $2.38 \mathrm{~g}$ of 7 was obtained, $94 \%$ yield.

$[\alpha]_{\mathrm{D}}^{25}=+10.0\left(c\right.$ o.8, $\left.\mathrm{CHCl}_{3}\right) .{ }^{1} \mathbf{H}$ NMR (250 $\left.\mathbf{M H z}, \mathbf{C D C l}_{3}\right) \delta$ 5.09 (t, J 7.0 Hz, $1 \mathrm{H}), 3.21(\mathrm{dd}, J 9.5,4.9 \mathrm{~Hz}, 1 \mathrm{H}), 3.12(\mathrm{dd}, J$ 9.5, $6.2 \mathrm{~Hz}, 1 \mathrm{H}), 1.98$ (dt, J 12.9, $6.3 \mathrm{~Hz}, 2 \mathrm{H}), 1.69(\mathrm{~s}, 3 \mathrm{H}), 1.61(\mathrm{~s}$, $3 \mathrm{H}), 1.56-1.42(\mathrm{~m}, 2 \mathrm{H}), 1.36-1.10(\mathrm{~m}, 4 \mathrm{H}), 0.95(\mathrm{~d}, J 6.5 \mathrm{~Hz}$, $\left.{ }_{3} \mathrm{H}\right), 0.87\left(\mathrm{~d}, J 6.5 \mathrm{~Hz},{ }_{3} \mathrm{H}\right) .{ }^{13} \mathrm{C}\left\{{ }^{1} \mathbf{H}\right\}$ NMR (62.5 $\left.\mathbf{M H z}, \mathbf{C D C l}_{3}\right)$ $\delta$ 131.2, 124.7, 44.0, 37.5, 32.4, 29.8, 25.7, 25.4, 20.3, 19.5, 18.5, 17.7. IR (Film) 2960, 2913, 2869, 2850, 1455, 1377, $817 \mathrm{~cm}^{-1}$. HRMS (ESI+) $\mathrm{m} / \mathrm{z}$ calculated for $\mathrm{C}_{12} \mathrm{H}_{24} \mathrm{I}[\mathrm{M}+\mathrm{H}]^{+}$295.0879, found 295.0908 .

4.1.8. (E)-Ethyl 3-ethyl-5-(trimethylsilyl)pent-2-en-4ynoate (19): A mixture of $\mathrm{Pd}(\mathrm{AcO})_{2}(337 \mathrm{mg}, 1.50 \mathrm{mmol})$ and tris-(2,6-dimethoxyphenyl)-phosphine (664 mg, $1.50 \mathrm{mmol})$ in THF (50.0 mL) was stirred for $30 \mathrm{~min}$. Then, $8(6.60 \mathrm{~mL}$, $50.0 \mathrm{mmol}$ ) was added and the mixture was stirred for another 10 minutes. After this time, 9 (7.00 $\mathrm{mL}$, $50.0 \mathrm{mmol})$ was added and the reaction was stirred for $18 \mathrm{~h}$. Thus, the solvent was removed and the residue was purified by flash chromatography, eluting with pentane:EtOAc 90:10 to provide $9.36 \mathrm{~g}$ of $19,85 \%$ yield.

$\mathbf{R f}=\mathbf{0 . 7 2}$ (hexane:EtOAc 95:5). ${ }^{\mathbf{H}} \mathbf{H}$ NMR (40o $\mathbf{M H z}, \mathbf{C D C l}_{\mathbf{3}}$ ) $\delta 6.06\left(\mathrm{t}, J 1.0 \mathrm{~Hz},{ }_{1} \mathrm{H}\right), 4.16(\mathrm{q}, J 7.1 \mathrm{~Hz}, 2 \mathrm{H}), 2.74(\mathrm{qd}, J 7.6,1.0$ $\mathrm{Hz}, 2 \mathrm{H}), 1.28$ (t, J 7.1 Hz, $3 \mathrm{H}), 1.15$ (t, J 7.6 Hz, $3 \mathrm{H}), 0.2(\mathrm{~s}, 9 \mathrm{H})$. ${ }^{13} \mathbf{C}\left\{{ }^{1} \mathrm{H}\right\}$ NMR (10o MHz, $\left.\mathrm{CDCl}_{3}\right) \delta 165.7,143.9,124.2,105.2$, 100.1, 6o.0, 25.4, 14.2, 12.8, 0.3 ( ${ }_{3} \mathrm{C}$ ). IR (Film) 2996, 2932, 2878, 2147, 1718, $1612 \mathrm{~cm}^{-1}$. HRMS (ESI+) $\mathrm{m} / \mathrm{z}$ calculated for $\mathrm{C}_{12} \mathrm{H}_{21} \mathrm{O}_{2} \mathrm{Si}[\mathrm{M}+\mathrm{H}]^{+}$225.1311, found 225.1329.

4.1.9. $\quad(E)$-3-Ethyl- $N$-methoxy- $N$-methylpent-2-en-4ynamide (20)

4.1.9.a. To a solution of 19 (3.00 g, $13.4 \mathrm{mmol})$ in THF (111 mL) and $\mathrm{MeOH} / \mathrm{H}_{2} \mathrm{O}$ 1:1 (22.2 mL) was added $\mathrm{LiOH}(6.40 \mathrm{~g}, 267$ mmol). The reaction was stirred at reflux for $18 \mathrm{~h}$. Then the mixture was poured into an $\mathrm{Et}_{2} \mathrm{O} / \mathrm{H}_{2} \mathrm{O}$ 1:1 mixture (100 mL) and acidified with $\mathrm{N} \mathrm{HCl}(\mathrm{pH}$ 1.o). The layers were separated and the aqueous layer was extracted with $\mathrm{Et}_{2} \mathrm{O}(4 \times 25.0 \mathrm{~mL})$. The organic layer was washed with a saturated aqueous $\mathrm{NaCl}$ solution (25.0 mL), dried over $\mathrm{MgSO}_{4}$, filtered and concentrated under reduced pressure. The residue was purified by flash chromatography using hexane:EtOAc 6o:40 as eluent to afford $1.38 \mathrm{~g}$ of the respective carboxylic acid intermediate, $83 \%$ yield.

$\mathbf{R f}=0.15$ (hexane:EtOAc 80:20). MP 80-82 ${ }^{\circ} \mathrm{C} .{ }^{1} \mathbf{H}$ NMR (250 $\left.\mathbf{M H z}, \mathbf{C D C l}_{3}\right) \delta 6.13(\mathrm{~s}, 1 \mathrm{H}), 3.29(\mathrm{~s}, 1 \mathrm{H}), 2.77(\mathrm{q}, J$ 7.0 Hz, $2 \mathrm{H})$, $1.17\left(\mathrm{t}, J\right.$ 7.0 Hz, $\left.{ }_{3} \mathrm{H}\right) .{ }^{13} \mathbf{C}\{\mathbf{1} \mathbf{H}\}$ NMR (62.5 $\left.\mathbf{M H z} \mathbf{C D C l}_{3}\right) \delta_{171.1}$, 145.9, 124.4, 83.7, 83.4, 25.8, 12.7. IR (ATR) 3295, 2969, 2936, 2878, 2095, 1686, $1606 \mathrm{~cm}^{-1}$. HRMS (ESI+) $\mathrm{m} / \mathrm{z}$ calculated for $\mathrm{C}_{7} \mathrm{H}_{7} \mathrm{O}_{2}[\mathrm{M}-\mathrm{H}]^{-}$123.0452, found 123.0456 .

4.1.9.b. To a solution of this carboxylic acid (1.96 g, 15.8 $\mathrm{mmol})$ and $\mathrm{MeON}(\mathrm{Me}) \mathrm{H} \cdot \mathrm{HCl}(3.08 \mathrm{~g}, 31.6 \mathrm{mmol})$ in $\mathrm{CH}_{2} \mathrm{Cl}_{2}$ $(78.9 \mathrm{~mL})$, were added DMAP $(386 \mathrm{mg}, 16.0 \mathrm{mmol})$ and DCC $(6.52 \mathrm{~g}, 31.6 \mathrm{mmol})$. Then, $\mathrm{Et}_{3} \mathrm{~N}(4.40 \mathrm{~mL}, 31.6 \mathrm{mmol})$ was added dropwise. The reaction was stirred for $18 \mathrm{~h}$ at room temperature. The mixture was washed with $\mathrm{H}_{2} \mathrm{O}$ (30.0 mL) and $1 \mathrm{M} \mathrm{HCl}$ solution $(2 \times 15.0 \mathrm{~mL})$. The organic layer was dried over $\mathrm{MgSO}_{4}$, filtered and carefully concentrated (the product is volatile). The residue was purified by flash chromatography, eluting with hexane:EtOAc 80:20, to provide 1.6o g of the amide $20,60 \%$ yield. Note: A high vacuum pump was not used to remove residual solvents; they were removed by co-evaporation with $\mathrm{CHCl}_{3}$.

$\mathbf{R f}=0.28$ (hexane:EtOAc 80:20). ${ }^{\mathbf{1}} \mathbf{H}$ NMR (250 $\mathbf{M H z}, \mathbf{C D C l}_{3}$ ) $\delta 6.57(\mathrm{~s}, 1 \mathrm{H}), 3.68(\mathrm{~s}, 3 \mathrm{H}), 3.21(\mathrm{~s}, 3 \mathrm{H}), 3.11(\mathrm{~s}, 1 \mathrm{H}), 2.70(\mathrm{q}, J$ 7.5 Hz, 2H), $1.16\left(\mathrm{t}, J 7.5 \mathrm{~Hz},{ }_{3} \mathrm{H}\right) .{ }^{13} \mathbf{C}\{\mathbf{H}\}$ NMR (62.5 MHz, $\left.\mathrm{CDCl}_{3}\right) \delta 166.2,139.8,123.9,84.5,80.3,61.6,32.1,25.5,12.8$. IR (ATR) 3287, 3238, 2971, 2938, 2878, 2838, 2091, 1643, 1607 $\mathrm{cm}^{-1}$. HRMS (ESI+) $\mathrm{m} / \mathrm{z}$ calculated for $\mathrm{C}_{9} \mathrm{H}_{14} \mathrm{NO}_{2}[\mathrm{M}+\mathrm{H}]^{+}$ 168.1024 , found 168.1054 .

4.1.10. (E)-3-Ethyl- $N$-methoxy- $N$-methylpent-2,4dienamide (10): To a solution of acetylene $20(806 \mathrm{mg}, 4.82$ $\mathrm{mmol})$ in benzene $(24.1 \mathrm{~mL})$, were added quinoline (o.14 $\mathrm{mL}$, $0.96 \mathrm{mmol}$ ) and Lindlar's catalyst (718 $\mathrm{mg}, 0.24 \mathrm{mmol})$. The reaction was stirred under $\mathrm{H}_{2}$ atmosphere for $30 \mathrm{~min}$. The reaction mixture was filtered under Celite ${ }^{\circledR}$ and eluted with $\mathrm{CH}_{2} \mathrm{Cl}_{2}$. The solvent was carefully evaporated (the product is volatile). The residue was purified by flash chromatography using $\mathrm{CH}_{2} \mathrm{Cl}_{2}$ :hexane 6o:40 as eluent to provide $600 \mathrm{mg}$ of the diene 10, $72 \%$ yield. Note: A high vacuum pump was not used to remove residual solvents; they were removed by coevaporation with $\mathrm{CHCl}_{3}$.

Rf = 0.28 (hexane:EtOAc 80:20). ${ }^{1} \mathbf{H}$ NMR (250 $\mathbf{~ M H z}, \mathbf{C D C l}_{3}$ ) $\delta 6.29\left(\mathrm{dd}, J 17.5,10.7 \mathrm{~Hz},{ }_{1 H}\right), 6.15(\mathrm{~s}, 1 \mathrm{H}), 5.4(\mathrm{~d}, J 17.4 \mathrm{~Hz}$, $1 \mathrm{H}), 5.27(\mathrm{~d}, J 10.7 \mathrm{~Hz}, 1 \mathrm{H}), 3.62(\mathrm{~s}, 3 \mathrm{H}), 3.17(\mathrm{~s}, 3 \mathrm{H}), 2.71(\mathrm{q}, J$ $7.5 \mathrm{~Hz}, 2 \mathrm{H}), 1.7\left(\mathrm{t}, J 7.5 \mathrm{~Hz},{ }_{3} \mathrm{H}\right) .{ }^{13}{ }^{1}\left\{{ }^{1} \mathbf{H}\right\}$ NMR (62.5 MHz, $\left.\mathrm{CDCl}_{3}\right) \delta 167.5,155.5,139.2,117.8,117.5,61.4,32.2$, 20.4, 14.0. IR (film) 3093, 2970, 2937, 2877, 2819, 2091, 1651, 1619, 1599 $\mathrm{cm}^{-1}$. HRMS (ESI+) $\mathrm{m} / \mathrm{z}$ calculated for $\mathrm{C}_{9} \mathrm{H}_{16} \mathrm{NO}_{2}[\mathrm{M}+\mathrm{H}]^{+}$ 170.1181, found 170.1162 .

4.1.11. $\quad\left({ }_{7} R, 9 S, E\right)-3$-Ethyl-7,9,13-trimethyltetradeca-1,3,12trien-5-one (22): ${ }^{25}$ To a solution of the iodide 7 (1.09 g, 3.72 $\mathrm{mmol})$ in $\mathrm{Et}_{2} \mathrm{O}(12.0 \mathrm{~mL})$ at $-78^{\circ} \mathrm{C}$ was added dropwise a 1.7 $\mathrm{M}$ solution of $t \mathrm{BuLi}(4.37 \mathrm{~mL}, 7.44 \mathrm{mmol})$. The reaction was stirred at this temperature for $30 \mathrm{~min}$. The temperature was thus allowed to reach room temperature for $2 \mathrm{~h}$. After this time, the mixture was cooled again to $-78^{\circ} \mathrm{C}$ and a solution of the amide $10(538 \mathrm{mg}, 3.18 \mathrm{mmol})$ in $\mathrm{Et}_{2} \mathrm{O}(3.90 \mathrm{~mL})$ was added dropwise. The reaction was stirred for $1 \mathrm{~h}$ at this temperature. The cold bath was removed, and the temperature was allowed to reach room temperature. Then, $\mathrm{NH}_{4} \mathrm{Cl}$ (15.0 $\mathrm{mL}$ ) was added, the layers were separated, and the aqueous layer was extracted with $\mathrm{Et}_{2} \mathrm{O}(3 \mathrm{x}$ 10.0 $\mathrm{mL}$ ). The organic extracts were combined, washed with saturated aqueous $\mathrm{NaHCO}_{3}$ (10.0 mL), dried over $\mathrm{MgSO}_{4}$, filtered and concentrated under reduced pressure. The residue obtained was purified by flash chromatography, eluting with 95:5 hexane:EtOAc to afford $510 \mathrm{mg}$ of triene 22, $58 \%$ yield.

'H NMR (50o MHz, $\mathbf{C D C l}_{3}$ ) $\delta 6.29$ (dd, $J$ 17.5, $\left.10.8 \mathrm{~Hz},{ }_{1} \mathrm{H}\right)$, $6.09(\mathrm{~s}, 1 \mathrm{H}), 5.70(\mathrm{~d}, J 17.4 \mathrm{~Hz}, 1 \mathrm{H}), 5.46(\mathrm{~d}, J 10.7 \mathrm{~Hz}, 1 \mathrm{H}), 5.11$ $(\mathrm{t}, J$ 7.1 Hz, $1 \mathrm{H}), 2.81-2.72(\mathrm{~m}, 2 \mathrm{H}), 2.43(\mathrm{dd}, J$ 15.1, $5.8 \mathrm{~Hz}$, $1 \mathrm{H})$, 2.30 (dd, J 15.2, 7.9 Hz, $1 \mathrm{H}), 2.16-2.11(\mathrm{~m}, 1 \mathrm{H})$, 2.01-1.95 (m, $2 \mathrm{H}), 1.7 \mathrm{O}(\mathrm{s}, 3 \mathrm{H}), 1.62(\mathrm{~s}, 3 \mathrm{H}), 1.56-1.47(\mathrm{~m}, 1 \mathrm{H}), 1.33-1.26(\mathrm{~m}$, $1 \mathrm{H}), 1.20-1.14(\mathrm{~m}, 2 \mathrm{H}), 1.14-1.07(\mathrm{~m}, 4 \mathrm{H}), 0.89(\mathrm{~d}, J 4.0 \mathrm{~Hz}$, $\left.{ }_{3} \mathrm{H}\right), 0.90\left(\mathrm{~d}, J 4.0 \mathrm{~Hz},{ }_{3} \mathrm{H}\right) .{ }^{13} \mathrm{C}\left\{{ }^{1} \mathbf{H}\right\}$ NMR (125 $\left.\mathbf{M H z}, \mathbf{C D C l}_{3}\right) \delta$ 
201.3, 156.2, 139.2, 131.1, 126.3, 124.9, 120.0, 53.0, 44.5, 37.8, 29.7, 29.2, 27.3, 25.7, 25.5, 20.5, 19.3, 17.7, 13.9.

4.1.12. $\quad(4 S, 6 R, E)$-10-Ethyl-4,6-dimethyl-8-oxododeca-9,11dienal (Fragment $\left.\mathrm{C}_{1}-\mathrm{C}_{12}\right)^{26}$

4.1.12.a. To a solution of polyene $22(92.0 \mathrm{mg}, 0.33 \mathrm{mmol})$ in $t \mathrm{BuOH}(1.70 \mathrm{~mL})$ and $\mathrm{H}_{2} \mathrm{O}(1.70 \mathrm{~mL})$ were added $\mathrm{K}_{3} \mathrm{Fe}(\mathrm{CN})_{6}$ (329 mg, $1.00 \mathrm{mmol}$ ), $\mathrm{K}_{2} \mathrm{CO}_{3}$ (138 mg, $1.00 \mathrm{mmol}$ ), $\mathrm{MeSO}_{4} \mathrm{NH}_{2}$ (31.7 mg, $0.33 \mathrm{mmol}),(\mathrm{DHQ})_{2}$ PHAL (13.0 mg, $0.02 \mathrm{mmol}$ ) and $\mathrm{K}_{2} \mathrm{OsO}_{4} \cdot 2 \mathrm{H}_{2} \mathrm{O}(1.20 \mathrm{mg}, 3.30 \mu \mathrm{mol})$. The reaction was stirred for $20 \mathrm{~h}$ at $\mathrm{o}{ }^{\circ} \mathrm{C}$. After this time, $\mathrm{Na}_{2} \mathrm{SO}_{3}\left(460 \mathrm{mg}\right.$ ) and $\mathrm{H}_{2} \mathrm{O}$ (10.0 $\mathrm{mL}$ ) were added to the reaction mixture. The layers were separated and the aqueous layer extracted with EtOAc $(5 \times 10.0 \mathrm{~mL})$. The organic extracts combined were dried over $\mathrm{MgSO}_{4}$, filtered and concentrated under reduced pressure. The resulting residue was purified by flash chromatography using hexane:EtOAc 60:40 as eluent. After purification 41.0 $\mathrm{mg}$ of the diol intermediate was obtained.

4.1.12.b. To a solution of this diol (41.0 $\mathrm{mg}$, $0.13 \mathrm{mmol}$ ) in $\mathrm{H}_{2} \mathrm{O}$ $(260 \mu \mathrm{L})$ and THF $(1.06 \mathrm{~mL})$ was added $\mathrm{NaIO}_{4}(151 \mathrm{mg}, 0.79$ $\mathrm{mmol}$ ) and the reaction was stirred for $2 \mathrm{~h}$. After this time, the reaction was quenched by the addition of a saturated aqueous $\mathrm{NaCl}$ solution ( $0.50 \mathrm{~mL}$ ). The layers were separated and the aqueous layer was extracted with $\mathrm{CH}_{2} \mathrm{Cl}_{2}(3 \times 0.50$ $\mathrm{mL}$ ). The organic extracts combined were dried over $\mathrm{MgSO}_{4}$, filtered and concentrated under reduced pressure. The resulting residue was purified by flash chromatography using hexane:EtOAc 90:10 as eluent. After purification, 30.0 mg of the fragment $\mathrm{C}_{1}-\mathrm{C}_{12}$ was obtained, $36 \%$ yield (2 steps).

'H NMR (50o MHz, $\left.\mathbf{C D C l}_{3}\right) \delta 9.77(\mathrm{t}, J \mathbf{1 . 8 ~ H z , ~} 1 \mathrm{H}), 6.27(\mathrm{dd}, J$ $17.4,10.8 \mathrm{~Hz}, 1 \mathrm{H}), 6.07(\mathrm{~s}, 1 \mathrm{H}), 5.69(\mathrm{~d}, J 17.4 \mathrm{~Hz}, 1 \mathrm{H}), 5.45(\mathrm{~d}, J$ $10.7 \mathrm{~Hz}, 1 \mathrm{H}), 2.73(\mathrm{q}, J 7.6,2 \mathrm{H}), 2.42\left(\mathrm{~m},{ }_{3} \mathrm{H}\right), 2.30\left(\mathrm{~m},{ }_{1} \mathrm{H}\right), 2.13$ $(\mathrm{m}, 1 \mathrm{H}), 1.63(\mathrm{~m}, 1 \mathrm{H}), 1.48(\mathrm{~m}, 2 \mathrm{H}), 1.13(\mathrm{~m}, 2 \mathrm{H}), 1.09(\mathrm{t}, J 7.6$ $\left.\mathrm{Hz},{ }_{3} \mathrm{H}\right), 0.89\left(\mathrm{~d}, J 3.5 \mathrm{~Hz},{ }_{3} \mathrm{H}\right), 0.87\left(\mathrm{~d}, J 3.7 \mathrm{~Hz},{ }_{3} \mathrm{H}\right) .{ }^{13} \mathbf{C}\left\{{ }^{1} \mathbf{H}\right\}$ NMR (125 MHz, $\mathrm{CDCl}_{3}$ ) $\delta$ 202.8, 201.0, 156.4, 139.2, 126.2, 120.2, 52.9, 44.2, 41.7, 29.8, 29.6, 27.1, 20.5, 19.6, 19.0, 14.o.

4.1.13. (E)-Pent-3-enoyl chloride (30):13b Freshly distilled oxalyl chloride $(15.6 \mathrm{~mL}, 182 \mathrm{mmol})$ was slowly added to a solution of (E)-pent-3-enoic acid ( $9.24 \mathrm{~mL}, 91.0 \mathrm{mmol})$ at 45 ${ }^{\circ} \mathrm{C}$. The reaction was stirred for $3 \mathrm{~h}$, warmed up to $70^{\circ} \mathrm{C}$ and stirred for 30 minutes. Excess of oxalyl chloride was removed under reduced pressure and the crude material was purified by distillation to provide $4.60 \mathrm{~g}$ of $30,42 \%$ yield.

'H NMR (250 MHz, $\left.\mathbf{C D C l}_{3}\right) \delta 5.70\left(\mathrm{~m},{ }_{1} \mathrm{H}\right), 5.52\left(\mathrm{~m},{ }_{1} \mathrm{H}\right), 3.54$ (dt, J 6.6, 1.1 Hz, 2H), 1.73 (dd, J6.0, $1.2 \mathrm{~Hz},{ }_{3} \mathrm{H}$ ).

4.1.14. Dimethyl 2-methyl-3-(E)-pent-3-enoylmaleate (31): MeLi 1.6 M (20.1 mL, $32.2 \mathrm{mmol})$ was added dropwise to a mixture of $\mathrm{CuCN}(2.80 \mathrm{~g}, 32.2 \mathrm{mmol})$ in THF (117 mL) at -40 ${ }^{\circ} \mathrm{C}$, after 30 minutes the mixture was cooled down to $-78{ }^{\circ} \mathrm{C}$ and commercially available diester 29 (3.59 mL, $29.2 \mathrm{mmol})$ was added for 5 minutes. After $2.5 \mathrm{~h}$, 30 (6.75 g, $43.9 \mathrm{mmol})$ was added at once and the reaction was stirred for $2 \mathrm{~h}$. The reaction was warmed up to ${ }^{\circ}{ }^{\circ} \mathrm{C}$ and quenched by the addition of $\mathrm{H}_{2} \mathrm{O}(14.0 \mathrm{~mL})$. The mixture was filtered under Celite ${ }^{\circledR}$ and eluted with $\mathrm{Et}_{2} \mathrm{O}$. The mixture was washed with saturated aqueous solution of $\mathrm{NaCl}(70.0 \mathrm{~mL})$. The layers were separated, and the aqueous layer was extracted with $\mathrm{Et}_{2} \mathrm{O}(2 \mathrm{x}$ $50.0 \mathrm{~mL}$ ). The combined organic layers were dried over $\mathrm{MgSO}_{4}$, filtrated and concentrated under reduced pressure. The crude material was purified by flash chromatography, eluted with hexane:AcOEt 85:15 to provide $4.10 \mathrm{~g}$ of 31, $58 \%$ yield.

Rf = 0.36 (hexane:AcOEt 8o:20). ${ }^{\mathbf{1}} \mathbf{H}$ NMR (250 $\mathbf{~ M H z}, \mathbf{C D C l}_{3}$ ) $\delta 5.63-5.41(\mathrm{~m}, 2 \mathrm{H}), 3.81\left(\mathrm{~s},{ }_{3} \mathrm{H}\right), 3.78(\mathrm{~s}, 3 \mathrm{H}), 3.39-3.28(\mathrm{~m}$,
2H), $2.01(\mathrm{~s}, 3 \mathrm{H}), 1.70\left(\mathrm{~d}, J 4.9 \mathrm{~Hz},{ }_{3} \mathrm{H}\right) .{ }^{13} \mathbf{C}\left\{{ }^{1} \mathbf{H}\right\} \quad$ NMR (62.5 $\left.\mathrm{MHz}, \mathrm{CDCl}_{3}\right) \delta 199.2,168.3,164.1,142.3,134.8,130.6,121.3$, 52.4, 52.4, 46.3, 17.8, 17.0. IR (film) 2955, 1704, $1729 \mathrm{~cm}^{-1}$. HRMS (ESI+) $\mathrm{m} / \mathrm{z}$ calculated for $\mathrm{C}_{12} \mathrm{H}_{16} \mathrm{O}_{5} \mathrm{Na}[\mathrm{M}+\mathrm{Na}]^{+}$ 263.0895, found 263.0884 .

4.1.15. Dimethyl 2-((R,E)-1-hydroxypent-3-enyl)-3methylmaleate (32): (+)-DIPCl (11.0 mL, $19.8 \mathrm{mmol})$ was added to a solution of $31(3.17 \mathrm{~g}, 13.2 \mathrm{mmol})$ in freshly distilled THF (66.o mL) at $-78^{\circ} \mathrm{C}$. The reaction was warmed up to -20 ${ }^{\circ} \mathrm{C}$ and stirred for 3 days at that temperature. Then, the reaction was warmed up to ${ }^{\circ}{ }^{\circ} \mathrm{C}$. The reaction was quenched by the addition of a solution of $\mathrm{H}_{2} \mathrm{O}_{2} 30 \%(1.70 \mathrm{~mL})$, and $\mathrm{MeOH}$ (30.0 $\mathrm{mL}$ ), and the mixture obtained was stirred for $2 \mathrm{~h}$. Thus, the organic solvent was removed under reduced pressure and the aqueous layer was extracted with $\mathrm{Et}_{2} \mathrm{O}(3 \mathrm{x} 10.0$ $\mathrm{mL}$ ). The combined organic layers were dried over $\mathrm{MgSO}_{4}$, filtrated and concentrated under reduced pressure. The crude material was purified by flash chromatography, eluted with hexane:AcOEt 3:1 to provide $2.20 \mathrm{~g}$ of 32, 70\% yield.

Rf = 0.33 (hexane:AcOEt 3:2). $[\alpha]_{\mathrm{D}}^{25}=-17.0\left(\right.$ c 1.1, $\left.\mathrm{CHCl}_{3}\right) .{ }^{\mathbf{1}} \mathbf{H}$ NMR (250 MHz, $\left.\mathrm{CDCl}_{3}\right) \delta 5.63-5.58\left(\mathrm{~m},{ }_{1} \mathrm{H}\right), 5.47-5.30(\mathrm{~m}$, $1 \mathrm{H}), 4.53(\mathrm{~s}, 1 \mathrm{H}), 3.75(\mathrm{~s}, 3 \mathrm{H}), 3.71(\mathrm{~s}, 3 \mathrm{H}), 2.71(\mathrm{~s}, 1 \mathrm{H}), 2.55-$ $2.37(\mathrm{~m}, 1 \mathrm{H}), 2.37-2.22(\mathrm{~m}, 1 \mathrm{H}), 1.91(\mathrm{~s}, 3 \mathrm{H}), 1.64(\mathrm{~d}, J 6.1 \mathrm{~Hz}$, $\left.{ }_{3} \mathrm{H}\right) .{ }^{13} \mathrm{C}\left\{{ }^{1} \mathrm{H}\right\}$ NMR (62.5 MHz, $\left.\mathrm{CDCl}_{3}\right) \delta 168.3,168.0,141.9$, 130.5, 129.5, 125.8, 69.5, 52.3, 52.1, 39.1, 17.9, 14.6. IR (Film) 3477 (br), 3026, 3001, 2953, 2919, $2857 \mathrm{~cm}^{-1}$. HRMS (ESI+) $\mathrm{m} / \mathrm{z}$ calculated for $\mathrm{C}_{12} \mathrm{H}_{18} \mathrm{O}_{5} \mathrm{Na}[\mathrm{M}+\mathrm{Na}]+265.1052$, found 265.1021. e.r. 86:14; $\boldsymbol{S}$-32 Retention Time 11 minutes and $\boldsymbol{R}-\mathbf{3 2}$ Retention Time: 9 minutes (Chiralpak $\mathrm{IC}^{\circledR}$, hexane:iPrOH 8:2, 1.0 $\mathrm{mL} / \mathrm{min}, 254 \mathrm{~nm})$.

4.1.16. Dimethyl 2-((R,E)-1-((tert-butyldimethylsilyl)oxy) pent-3-en-1-il)-3-methylmaleate (33): 2,6-lutidine (1.45 mL, $12.4 \mathrm{mmol})$ and TBSOTf $(1.78 \mathrm{~mL}, 8.30 \mathrm{mmol})$ were added slowly to a solution of 32 (1.00 g, $4.15 \mathrm{mmol}$ ) in $\mathrm{CH}_{2} \mathrm{Cl}_{2}(41.5$ $\mathrm{mL})$ at $\mathrm{o}{ }^{\circ} \mathrm{C}$. The reaction was stirred for $1 \mathrm{~h}$, after which the reaction was quenched by the addition of a saturated aqueous solution of $\mathrm{NaHCO}_{3}(15.0 \mathrm{~mL})$. The layers were separated, and the aqueous layer was extracted with $\mathrm{CH}_{2} \mathrm{Cl}_{2}(2 \times 30.0$ $\mathrm{mL})$. The combined organic layers were dried over $\mathrm{MgSO}_{4}$, filtrated and concentrated under reduced pressure. The crude material was purified by flash chromatography, eluted with hexane:AcOEt 90:10 to provide $1.39 \mathrm{~g}$ of 33, 94\% yield.

$\mathbf{R f}=0.29$ (hexane:AcOEt 90:10). $[\alpha]_{\mathrm{D}}^{25}=-7.0\left(c\right.$ 1.1, $\left.\mathrm{CHCl}_{3}\right) .{ }^{\mathbf{1}} \mathbf{H}$ NMR (250 MHz, $\left.\mathbf{C D C l}_{3}\right) \delta 5.55-5.44\left(\mathrm{~m},{ }_{1} \mathrm{H}\right), 5.43-5.28(\mathrm{~m}$, $1 \mathrm{H}), 4.51(\mathrm{dd}, J 8.1,5.7 \mathrm{~Hz}, 1 \mathrm{H}), 3.71(\mathrm{~d}, J 3.8 \mathrm{~Hz}, 6 \mathrm{H}), 2.58-$ $2.42(\mathrm{~m}, 1 \mathrm{H}), 2.41-2.24(\mathrm{~m}, 1 \mathrm{H}), 1.90(\mathrm{~s}, 3 \mathrm{H}), 1.62(\mathrm{~d}, J 6.2 \mathrm{~Hz}$, $3 \mathrm{H})$, o.84 (s, 9H), o.01 (d, J $6.5 \mathrm{~Hz}, 6 \mathrm{H}) .{ }^{13} \mathbf{C}\left\{{ }^{1} \mathbf{H}\right\}$ NMR (62.5 MHz, $\left.\mathrm{CDCl}_{3}\right) \delta$ 168.2, 167.9, 145.1, 128.5, 127.3, 126.8, 71.4, 52.2, 51.7, 40.0, 25.6 (3C), 18.1, 17.9, 14.4, -5.0, -5.2. IR (film) 3025, 2952, 2930, 2857, $1731 \mathrm{~cm}^{-1}$. HRMS (ESI+) $\mathrm{m} / \mathrm{z}$ calculated for $\mathrm{C}_{18} \mathrm{H}_{33} \mathrm{O}_{5} \mathrm{Si}[\mathrm{M}+\mathrm{H}]^{+}$357.2097, found 357.2094.

4.1.17. Methyl 1-((2-(trimethylsilyl)ethoxy)methyl) 2((R,E)-1-((tert-butyldimethylsilyl)oxy)pent-3-en-1-il)-3-

metylmaleate and Methyl 4-((2trimethylsilyl)ethoxy)methyl) 2-((R,E)-1-((tertbutyldimethylsilyl)oxy)pent-3-en-1-yl)-3-methylmaleate (34)

4.1.17.a. $\mathrm{LiOH}(757 \mathrm{mg}, 31.6 \mathrm{mmol})$ was added to a solution of 33 (751 mg, $2.11 \mathrm{mmol})$ in THF $(15.8 \mathrm{~mL})$ and $\mathrm{H}_{2} \mathrm{O}(5.30 \mathrm{~mL})$ at $\mathrm{o}{ }^{\circ} \mathrm{C}$. The reaction was warmed up to room temperature and stirred for $18 \mathrm{~h}$, at which time $\mathrm{HCl} 1 \mathrm{M}(29.0 \mathrm{~mL})$ was added $(\mathrm{pH}=3.0)$. Then, the reaction was heated up to $60^{\circ} \mathrm{C}$ 
until the appearance of a spot on the TLC ( $\mathrm{Rf}=0.3$, hexane:AcOEt 80:20) with concomitant disappearance of the spot observed on the baseline of the TLC (i.e. dicarboxylic acid intermediate). The THF was removed under reduced pressure and aqueous layer was extracted with AcOEt $(5 \mathrm{x}$ $20.0 \mathrm{~mL}$ ). The combined organic layers were dried over $\mathrm{MgSO}_{4}$, filtrated and concentrated under reduced pressure. The crude compound was then engaged in the next step without further purification.

4.1.17.b. Dried MeOH (o.20 mL, $5.05 \mathrm{mmol}$ ) was added into a solution containing the residue of the previous step in $\mathrm{CH}_{2} \mathrm{Cl}_{2}(4.20 \mathrm{~mL})$ dropwise at $\mathrm{o}{ }^{\circ} \mathrm{C}$. The, DIPA (o.83 mL, 5.79 $\mathrm{mmol}$ ) was added dropwise. After 50 minutes, SEMCl (o.56 $\mathrm{mL}, 3.16 \mathrm{mmol}$ ) was added. The reaction was stirred for $1 \mathrm{~h}$ at $0{ }^{\circ} \mathrm{C}$. After this time, the reaction was washed with $\mathrm{H}_{2} \mathrm{O}(3 \mathrm{x}$ 2.0o $\mathrm{mL}$ ), and the organic layer was dried over $\mathrm{MgSO}_{4}$, filtrated and concentrated under reduced pressure. The crude material was purified by flash chromatography, eluted with hexane:AcOEt 8o:20 to provide $642 \mathrm{mg}$ of $34,67 \%$ yield (2 steps).

$\mathbf{R f}=0.43$ (hexane:AcOEt 8o:20). $[\alpha]_{\mathrm{D}}^{25}=-6.0$ (c 1.14, $\mathrm{CHCl}_{3}$ ). 'H NMR (250 MHz, $\left.\mathbf{C D C l}_{3}\right) \delta 5.62-5.22(\mathrm{~m}, 4 \mathrm{H}), 4.62-4.47$ $(\mathrm{m}, 1 \mathrm{H}), 3.83-3.63(\mathrm{~m}, 5 \mathrm{H}), 2.60-2.45(\mathrm{~m}, 1 \mathrm{H}), 2.43-2.25$ $(\mathrm{m}, 1 \mathrm{H}), 1.93(\mathrm{~s}, 3 \mathrm{H}), 1.64(\mathrm{~d}, J 5.8 \mathrm{~Hz}, 3 \mathrm{H}), 1.01-0.91(\mathrm{~m}, 2 \mathrm{H})$, $0.86(\mathrm{~s}, 9 \mathrm{H})$, $0.06(\mathrm{~s}, 3 \mathrm{H}), 0.04(\mathrm{~s}, 3 \mathrm{H}), 0.03(\mathrm{~s}, 9 \mathrm{H}) .{ }^{13} \mathbf{C}\left\{{ }^{1} \mathbf{H}\right\}$ NMR (125 MHz, CDCl $) \delta$ 168.1, 167.3, 144.4, 128.6, 126.9, 90.1, 71.5, 68.1, 52.2, 40.1, 32.0, 29.7, 25.7 (3C), 18.1, 18.0, 14.7, -1.4 (3C), -4.9, -5.1. IR (film) 2954, 2927, $1730 \mathrm{~cm}^{-1}$. HRMS (ESI+) $\mathrm{m} / \mathrm{z}$ calculated for $\mathrm{C}_{23} \mathrm{H}_{44} \mathrm{NaO}_{6} \mathrm{Si}_{2}[\mathrm{M}+\mathrm{Na}]^{+}$495.2574, found 495.2581 .

4.1.18. $\quad(R, Z)-3-(($ tert-Butyldimethylsilyloxy)-4(methoxycarbonyl)-5-methyl-6-oxo-6-((2-(trimethylsilyl) ethoxy) methoxy)hex-4-enoic acid and $(R, Z)-3-(($ tertbutyldimethylsilyloxy)-4-(methoxycarbonyl)-5-methyl6-oxo-6-((2-(trimethylsilyl)ethoxy)methoxy)hex-4-enoic acid (11)

4.1.18.a. NMO (219 mg, $1.87 \mathrm{mmol}$ ) and $\mathrm{OsO}_{4} 4 \%$ (o.24 mL, $0.04 \mathrm{mmol})$ were added to a solution of 34 in acetone (11.3 $\mathrm{mL})$ and $\mathrm{H}_{2} \mathrm{O}(1.13 \mathrm{~mL})$. The reaction was stirred for $2 \mathrm{~h}$ and then quenched by the addition of a saturated aqueous solution of $\mathrm{Na}_{2} \mathrm{~S}_{2} \mathrm{O}_{4}$ (30.0 $\mathrm{mL}$ ). The mixture was extracted with AcOEt $(3 \times 50.0 \mathrm{~mL})$. The combined organic layers were dried over $\mathrm{MgSO}_{4}$, filtrated and concentrated under reduced pressure. The residue was used in the next step without further purification.

4.1.18.b. PIDA (441 mg, $1.37 \mathrm{mmol}$ ) was added to a solution of the previously synthesized residue in $\mathrm{CH}_{2} \mathrm{Cl}_{2}(12.4 \mathrm{~mL})$. The reaction was stirred for $2 \mathrm{~h}$, and then filtered through a plug of silica gel and eluted with $\mathrm{CH}_{2} \mathrm{Cl}_{2}$. The solvent was removed under reduced pressure and engaged in the next step without further purification.

4.1.18.c. $\mathrm{NaH}_{2} \mathrm{PO}_{4}$ (383 mg, $3.19 \mathrm{mmol}$ ), 2-methyl-2-butene (o.51 mL, $4.79 \mathrm{mmol})$ and $\mathrm{NaClO}_{2}(125 \mathrm{mg}, 1.38 \mathrm{mmol})$ were added to a solution of the previously synthesized residue in $t \mathrm{BuOH}(12.1 \mathrm{~mL})$ and $\mathrm{H}_{2} \mathrm{O}(12.1 \mathrm{~mL})$. The reaction was stirred for $18 \mathrm{~h}$ and then quenched by the addition of a saturated aqueous solution of $\mathrm{NaCl}(15.0 \mathrm{~mL})$. The mixture was extracted with AcOEt ( 4 x $15.0 \mathrm{~mL}$ ). The combined organic layers were dried over $\mathrm{MgSO}_{4}$, filtrated and concentrated under reduced pressure. The crude material was purified by flash chromatography, eluted with hexane:AcOEt:formic acid 75:24:1 to provide $474 \mathrm{mg}$ of $\mathbf{1 1}, 80 \%$ yield.
Rf $=0.37$ (hexane:AcOEt:formic acid 75:24:1). $[\alpha]_{\mathrm{D}}^{25}=+\mathbf{2 . 0}(c$ 1.4, $\mathrm{CHCl}_{3}$ ). ${ }^{1} \mathbf{H}$ NMR (50o $\left.\mathbf{M H z}, \mathbf{C D C l}_{3}\right) \delta_{5.47-5.35}(\mathrm{~m}, \mathbf{2} \mathrm{H})$, 5.16 (dd, J 9.1, $3.9 \mathrm{~Hz}, 1 \mathrm{H}), 3.77(\mathrm{~s}, 3 \mathrm{H}), 3.75(\mathrm{~m}, 2 \mathrm{H}), 3.08-3.02$ $(\mathrm{m}, 1 \mathrm{H}), 2.73-2.67(\mathrm{~m}, 1 \mathrm{H}), 2.07(\mathrm{~d}, J 2.9 \mathrm{~Hz}, 3 \mathrm{H}), 1.05-0.98$ $(\mathrm{m}, 2 \mathrm{H}), 0.88(\mathrm{~m}, 9 \mathrm{H}), 0.11(\mathrm{~s}, 3 \mathrm{H})$, $0.09(\mathrm{~s}, 3 \mathrm{H}), 0.05(\mathrm{~s}, 9 \mathrm{H})$. ${ }^{13} \mathbf{C}\left\{{ }^{1} \mathrm{H}\right\}$ NMR (125 MHz, $\left.\mathrm{CDCl}_{3}\right) \delta$ 175.8, 168.1, 167.6, 167.0, 167.0, 142.8, 141.6, 130.8, 130.8, 90.3, 68.3, 67.4, 52.4, 52.1, 41.7, 29.7, 25.6 (3C), 18.1, 18.0, 14.9, 14.6, -1.44 (3C), -4.87, -5.44. IR (film) 3446, 2954, 2929, 2907, 2857, 1738, $1715 \mathrm{~cm}^{-1}$. HRMS (ESI+) $\mathrm{m} / \mathrm{z}$ calculated for $\mathrm{C}_{21} \mathrm{H}_{40} \mathrm{O}_{8} \mathrm{NaSi}_{2}[\mathrm{M}+\mathrm{Na}]^{+}$499.2159, found 499.2149 .

4.1.19. (2S)-Methyl 3-(4-methoxybenzyloxy)-2methylpropionate (36):42 To a solution of the $(S)$-Roche ester (2.6o g, $22.1 \mathrm{mmol})$ in $\mathrm{CH}_{2} \mathrm{Cl}_{2}(50.0 \mathrm{~mL})$ was added $p$ methoxybenzyl trichloroacetimidate $(9.36 \mathrm{~g}, 33.2 \mathrm{mmol})$ and camphorsulfonic acid ( $0.50 \mathrm{~g}, 1.14 \mathrm{mmol}$ ). The reaction mixture was stirred at room temperature for $18 \mathrm{~h}$. Thus, the mixture was diluted with $\mathrm{Et}_{2} \mathrm{O}(200 \mathrm{~mL})$ and washed with a saturated aqueous $\mathrm{NaHCO}_{3}$ solution $(2 \times 45.0 \mathrm{~mL})$ and $\mathrm{NaCl}$ (45.0 $\mathrm{mL})$, followed by $\mathrm{H}_{2} \mathrm{O}(2 \times 45.0 \mathrm{~mL})$. The organic extract was dried over $\mathrm{MgSO}_{4}$, filtered and concentrated under reduced pressure. The crude was purified by flash chromatography, eluting with pentane:EtOAc 90:10 to provide 5.90 g of protected ester $36,98 \%$ yield.

$[\alpha]_{\mathrm{D}}^{25}=+11.0\left(c\right.$ 1.1, $\left.\mathrm{CHCl}_{3}\right) .{ }^{\mathbf{1}} \mathbf{H}$ NMR (250 $\left.\mathbf{M H z}, \mathbf{C D C l}_{3}\right) \delta_{7.23}$ $(\mathrm{d}, J 8.5 \mathrm{~Hz}, 2 \mathrm{H}), 6.87(\mathrm{~d}, J 8.6 \mathrm{~Hz}, 2 \mathrm{H}), 4.45(\mathrm{~s}, 2 \mathrm{H}), 3.8 \mathrm{o}(\mathrm{s}$, $3 \mathrm{H}), 3.70(\mathrm{~s}, 3 \mathrm{H}), 3.69-3.57(\mathrm{~m}, 1 \mathrm{H}), 3.46(\mathrm{dd}, J$ 9.1, $5.9 \mathrm{~Hz}$, $\left.{ }_{1 H}\right), 2.85$ - $2.69\left(\mathrm{~m},{ }_{1} \mathrm{H}\right), 1.17(\mathrm{~d}, J$ 7.1 Hz, $3 \mathrm{H}) .{ }^{13} \mathbf{C}\left\{{ }^{1} \mathbf{H}\right\}$ NMR (62.5 $\left.\mathrm{MHz} \mathrm{CDCl}_{3}\right) \delta 175.3,159.2,130.2,129.2(2 \mathrm{C}), 113.7(2 \mathrm{C})$, 72.7, 71.6, 55.2, 51.7, 40.2, 14.0. IR (film) 3054, 2953, 2862, $1736 \mathrm{~cm}^{-1}$.

4.1.20. (2R)-3-(4-Methoxybenzyloxy)-2-methylpropan-1-ol (37):42 A solution of $1 \mathrm{M}$ DIBAL-H (61.0 mL, 61.0 mmol) was added into a solution of ester $36(5.80 \mathrm{~g}, 24.4 \mathrm{mmol})$ in $\mathrm{CH}_{2} \mathrm{Cl}_{2}(190 \mathrm{~mL})$ at $-78^{\circ} \mathrm{C}$. The reaction was stirred for $1 \mathrm{~h}$ at this temperature. Then, $\mathrm{MeOH}(40.0 \mathrm{~mL})$ was added followed by the addition of $\mathrm{H}_{2} \mathrm{O}(24.0 \mathrm{~mL})$ and an aqueous saturated solution of sodium and potassium tartrate (160 $\mathrm{mL}$ ). The mixture was stirred until complete homogenization of the organic phase. Thus, the layers were separated, and the aqueous one was extracted with $\mathrm{CH}_{2} \mathrm{Cl}_{2}(2 \times 50.0 \mathrm{~mL})$. The combined organic extracts were dried over $\mathrm{MgSO}_{4}$, filtered and concentrated under educed pressure. The crude material was purified by flash chromatography, eluted with pentane:AcOEt 8o:20 to provide $4.92 \mathrm{~g}$ of $37,96 \%$ yield.

$[\alpha]_{\mathrm{D}}^{25}=+14.8\left(\right.$ c 1.15, $\left.\mathrm{CHCl}_{3}\right) .{ }^{1} \mathbf{H}$ NMR (250 $\left.\mathbf{~ M H z}, \mathbf{C D C l}_{3}\right) \delta$ $7.24(\mathrm{~d}, J 8.7 \mathrm{~Hz}, 2 \mathrm{H}), 6.87(\mathrm{~d}, J 8.7 \mathrm{~Hz}, 2 \mathrm{H}), 4.43(\mathrm{~s}, 2 \mathrm{H}), 3.78$ (s, $3 \mathrm{H}), 3.57$ (d, J $6.3 \mathrm{~Hz}, 2 \mathrm{H}), 3.49-3.35$ (m, $2 \mathrm{H}), 2.72\left(\mathrm{sl},{ }_{1} \mathrm{H}\right)$, 2.13 - $1.91(\mathrm{~m}, 1 \mathrm{H}), 0.87\left(\mathrm{~d}, J\right.$ 7.0 Hz, $\left.{ }_{3} \mathrm{H}\right) .{ }^{13} \mathbf{C}\{\mathbf{H}\}$ NMR $(62.5$ $\left.\mathrm{MHz}, \mathrm{CDCl}_{3}\right) \delta$ 159.2, 130.2, 129.2 (2C), 113.8 (2C), 74.8, 73.0, 67.4, 55.2, 35.6, 13.5. IR (film). 3455 (br), 3016, 2960, 2864 $\mathrm{cm}^{-1}$.

4.1.21. (2R,3S)-4-(4-Methoxybenzyloxy)-3-methylbutan-2ol (12) ${ }^{14}$

4.1.21.a. A solution of oxalyl chloride ( $3.92 \mathrm{~mL}, 46.3 \mathrm{mmol})$ in $\mathrm{CH}_{2} \mathrm{Cl}_{2}$ (100 $\mathrm{mL}$ ) was slowly added to a solution of DMSO (4.80 $\mathrm{mL}, 68.8 \mathrm{mmol}$ ) in $\mathrm{CH}_{2} \mathrm{Cl}_{2}$ (10.0 mL) at $-78{ }^{\circ} \mathrm{C}$. The mixture was stirred for 10 minutes. Thus, a solution of alcohol 37 (4.8o g, $22.8 \mathrm{mmol}$ ) in $\mathrm{CH}_{2} \mathrm{Cl}_{2}$ (48.o mL) was slowly added to above mentioned mixture. After $1 \mathrm{~h}$ at $-78{ }^{\circ} \mathrm{C}, \mathrm{Et}_{3} \mathrm{~N}$ (15.8 $\mathrm{mL}, 114 \mathrm{mmol}$ ) was added dropwise. The reaction was quenched by addition of a saturated aqueous solution of 
$\mathrm{NH}_{4} \mathrm{Cl}$ (70.0 $\left.\mathrm{mL}\right)$. Then, the mixture was allowed to warm up to room temperature. The layers were separated, and the aqueous one was extracted with $\mathrm{Et}_{2} \mathrm{O}(3 \times 50.0 \mathrm{~mL})$. The combined organic extracts were washed with brine (50.0 $\mathrm{mL}$ ), dried over $\mathrm{MgSO}_{4}$, filtered and concentrated under reduced pressure to provide the aldehyde intermediate 38 which was used for the next step without further purification.

4.1.21.b. MeLi 1.6 M (54.1 mL, $86.6 \mathrm{mmol})$ was added to a solution of $\mathrm{CuI}(8.24 \mathrm{~g}, 43.4 \mathrm{mmol})$ in $\mathrm{Et}_{2} \mathrm{O}(24.0 \mathrm{~mL})$ at -20 ${ }^{\circ} \mathrm{C}$ for 15 minutes. Thus, the solution was cooled to $-78{ }^{\circ} \mathrm{C}$, and a solution of the above-mentioned aldehyde 38 in $\mathrm{Et}_{2} \mathrm{O}$ (32.0 $\mathrm{mL}$ ) was added dropwise. The reaction was stirred for 12 $h$, and quenched by the addition of a saturated aqueous solution of $\mathrm{NH}_{4} \mathrm{Cl}$ (30.0 mL) and warmed up to room temperature. The layers were separated, and the aqueous one was extracted with $\mathrm{Et}_{2} \mathrm{O}(2 \times 30.0 \mathrm{~mL})$. The combined organic extracts were washed with brine (20.0 $\mathrm{mL}$ ), dried over $\mathrm{MgSO}_{4}$, filtered and concentrated under reduced pressure. The crude material was purified by flash chromatography, eluted with pentane:AcOEt 3:1 to provide 3.80 g of alcohol 12 (d.r. 12:1), 75\% yield (2 steps).

$\mathbf{R f}=0.13$ (hexane:AcOEt 80:20). $[\alpha]_{\mathrm{D}}^{25}=+18.0\left(\mathrm{c}\right.$ o.9, $\left.\mathrm{CHCl}_{3}\right)$. 'H NMR (40o MHz, $\left.\mathbf{C D C l}_{3}\right) \delta_{7.25}(\mathrm{~d}, J 8.6 \mathrm{~Hz}, 2 \mathrm{H}), 6.89$ (d, $J$ $8.7 \mathrm{~Hz}, 2 \mathrm{H}), 4.47(\mathrm{~s}, 2 \mathrm{H}), 3.81(\mathrm{~s}, 3 \mathrm{H}), 3.67(\mathrm{~m}, 1 \mathrm{H}), 3.57(\mathrm{dd}, J$ 9.2, 4.2 Hz, $1 \mathrm{H}), 3.42$ (dd, J 9.3, 8.3 Hz, $1 \mathrm{H}), 2.93\left(\mathrm{sl},{ }_{1} \mathrm{H}\right), 1.78$ $(\mathrm{m}, 1 \mathrm{H}), 1.17(\mathrm{~d}, J 6.1 \mathrm{~Hz}, 3 \mathrm{H}), 0.85(\mathrm{~d}, J 7.1 \mathrm{~Hz}, 3 \mathrm{H}) .{ }^{13} \mathbf{C}\left\{{ }^{1} \mathbf{H}\right\}$

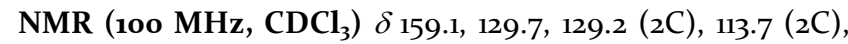
75.1, 72.9, 72.4, 55.1, 39.9, 20.9, 13.5. IR (film) 3432 (br), 2966, 2932, 2902, 2876, $2837 \mathrm{~cm}^{-1}$. HRMS (ESI+) $\mathrm{m} / \mathrm{z}$ calculated for $\mathrm{C}_{13} \mathrm{H}_{20} \mathrm{O}_{3} \mathrm{Na}[\mathrm{M}+\mathrm{Na}]^{+} 247.1310$; found 247.1303 .

4.1.22. $\quad\left({ }_{4} R,{ }_{5} S\right)$-2-(4-Methoxyphenyl)-4,5-dimethyl-1,3dioxane (39): DDQ (82.0 $\mathrm{mg}, 0.36 \mathrm{mmol})$ was added to a solution of alcohol $12(54.0 \mathrm{mg}, 0.24 \mathrm{mmol})$ in $\mathrm{CH}_{2} \mathrm{Cl}_{2}(2.00$ $\mathrm{mL}$ ) and phosphate buffer $\mathrm{pH} 7.0$ (o.40 $\mathrm{mL}$ ). The reaction was stirred for $1 \mathrm{~h}$ in an open flask, after which the reaction was quenched by the addition of a saturated aqueous solution of $\mathrm{NaHCO}_{3}(2.00 \mathrm{~mL})$. The mixture was filtered through a plug of Celite ${ }^{\circledR}$, a plug of silica gel and eluted with $\mathrm{CH}_{2} \mathrm{Cl}_{2}$. The layers were separated, and the organic one was dried over $\mathrm{MgSO}_{4}$, filtered and concentrated under reduced pressure. The crude material was purified by flash chromatography, eluted with hexane:AcOEt 90:10 to provide 24.0 mg of $39,45 \%$ yield.

$\mathbf{R f}=0.39$ (hexane:AcOEt 8o:20). $[\alpha]_{\mathrm{D}}^{25}=-10.0\left(\right.$ c 1.o, $\left.\mathrm{CHCl}_{3}\right)$. 'H NMR (40o MHz, $\left.\mathbf{C D C l}_{3}\right) \delta 7.46(\mathrm{~d}, J 8.6 \mathrm{~Hz}, 2 \mathrm{H}), 6.92(\mathrm{~d}, J$ $8.8 \mathrm{~Hz}, 2 \mathrm{H}), 5.49(\mathrm{~s}, 1 \mathrm{H}), 4.12(\mathrm{dd}, J 11.3,4.7 \mathrm{~Hz}, 1 \mathrm{H}), 3.83$ (s, $3 \mathrm{H}), 3.57(\mathrm{dd}, J 9.7,6.2 \mathrm{~Hz}, 1 \mathrm{H}), 3.51(\mathrm{t}, J 11.3 \mathrm{~Hz}, 1 \mathrm{H}), 1.89-$ $1.76(\mathrm{~m}, 1 \mathrm{H}), 1.35\left(\mathrm{~d}, J 6.2 \mathrm{~Hz},{ }_{3} \mathrm{H}\right), 0.83\left(\mathrm{~d}, J 6.7 \mathrm{~Hz},{ }_{3} \mathrm{H}\right)$. $\left.{ }_{13 C}{ }_{1} \mathbf{H}\right\}$ NMR (10o $\left.\mathbf{M H z}, \mathbf{C D C l}_{3}\right) \delta$ 159.9, 131.3, $127.4(2 \mathrm{C}), 113.6$ (2C), 101.2, 79.5, 73.0, 55.3, 35.9, 19.1, 12.5. IR (Film) 2962, 2917, 2849, 1614, 1518, $1250 \mathrm{~cm}^{-1}$. HRMS (ESI+) $\mathrm{m} / \mathrm{z}$ calculated for $\mathrm{C}_{13} \mathrm{H}_{19} \mathrm{O}_{3}[\mathrm{M}+\mathrm{H}]^{+}$223.1334, found 223.1364.

4.1.23. 1- $((2 R, 3 S)-4-((4-$ methoxybenzyl $)$ oxy $)-3-$ methylbutan-2-yl) 4-methyl 3-((2(trimethylsilyl)ethoxy)methyl) $\quad(R, Z)-2-(($ tert butyldimethylsilyl)oxy)pent-3-ene-1,3,4-tricarboxylate and $1-((2 R, 3 S)-4-((4-m e t h o x y b e n z y l)$ oxy $)-3-$ methylbutan2-yl) 3-methyl 4-((2-(trimethylsilyl)ethoxy)methyl) $(R, Z)-2-(($ tert-butyldimethylsilyl)oxy)pent-3-ene-1,3,4tricarboxylate (41): Acid $11(141 \mathrm{mg}, 0.63 \mathrm{mmol})$ in toluene (9.0o mL), 2,4,6-trichlorobenzoyl chloride (o.11 mL, o.69 mmol) and DMAP (230 $\mathrm{mg}, 1.88 \mathrm{mmol}$ ) were added to a solution of secondary alcohol $12(329 \mathrm{mg}, 0.69 \mathrm{mmol})$ in toluene $(22.4 \mathrm{~mL})$. Then, $\mathrm{Et}_{3} \mathrm{~N}(0.26 \mathrm{~mL}, 1.88 \mathrm{mmol})$ was added dropwise. The reaction was stirred for $4 \mathrm{~h}$ at room temperature. Thus, the reaction was quenched by the addition of a saturated aqueous solution of $\mathrm{NaHCO}_{3}(28.0 \mathrm{~mL})$ and extraction was performed with $\mathrm{CH}_{2} \mathrm{Cl}_{2}(3 \times 20.0 \mathrm{~mL})$. The combined organic layers were dried over $\mathrm{MgSO}_{4}$, filtrated and concentrated under reduced pressure. The crude material was purified by flash chromatography, eluted with hexane:AcOEt 80:20 to provide $390 \mathrm{mg}$ of ester 41, 91\% yield.

Rf = 0.36 (hexane:AcOEt: $4: 1) .[\alpha]_{\mathrm{D}}^{25}=-\mathbf{2 . 0}\left(c \mathrm{1.4}, \mathrm{CHCl}_{3}\right) .{ }^{\mathbf{1}} \mathbf{H}$ NMR (50o MHz, $\left.\mathbf{C D C l}_{3}\right) \delta 7.26(\mathrm{~d}, J 8.0 \mathrm{~Hz}, 2 \mathrm{H}), 6.89$ (d, $J$ $8.5 \mathrm{~Hz}, 2 \mathrm{H}$ ), $5.49-5.30(\mathrm{~m}, 2 \mathrm{H}), 5.17$ (ddd, J 9.8, 6.4, $3.8 \mathrm{~Hz}$, $1 \mathrm{H}$ ), 5.00 (quint, J $6.2 \mathrm{~Hz}, 1 \mathrm{H}$ ), $4.42(\mathrm{~d}, J 1.5 \mathrm{~Hz}, 2 \mathrm{H}$ ), 3.82 (s, $3 \mathrm{H}), 3.80-3.72(\mathrm{~m}, 5 \mathrm{H}), 3.41(\mathrm{ddd}, J 8.7,5.9,2.4 \mathrm{~Hz}, 1 \mathrm{H}), 3.35$ - $3.23(\mathrm{~m}, 1 \mathrm{H}), 2.94$ (ddd, J 16.0, 8.8, 7.3 Hz, 1H), 2.57 (td, J 16.3, 3.7 Hz, $1 \mathrm{H})$, $2.05(\mathrm{~s}, 4 \mathrm{H}), 1.22-1.15\left(\mathrm{~m},{ }_{3} \mathrm{H}\right)$, 1.02-0.94 (m, $\left.{ }_{5} \mathrm{H}\right), 0.87(\mathrm{~d}, J 3.8 \mathrm{~Hz}, 9 \mathrm{H}), 0.11\left(\mathrm{~s},{ }_{3} \mathrm{H}\right), 0.08\left(\mathrm{~s},{ }_{3} \mathrm{H}\right), 0.05(\mathrm{~s}$, 9H). ${ }^{13} \mathbf{C}\left\{{ }^{1} \mathbf{H}\right\}$ NMR (125 MHz, $\left.\mathbf{C D C l}_{3}\right) \delta$ 170.4, 170.3, 168.0, $167.7,167.0,166.9,159.1,143.6,142.5,130.6,129.2(2 \mathrm{C}), 113.7$ (2C), 90.1, 72.7, 72.5, 71.7, 68.2, 67.5, 67.4, 55.3, 52.3, 51.9, 42.1, 42.0, 37.9, 25.6 (3C), 18.0, 16.4, 14.8, 14.6, 12.8, -1.40 (3C), -4.9, -5.3. IR (film) 2953, 2942, 2898, 2857, 1738, $1732 \mathrm{~cm}^{-1}$. HRMS (ESI+) $\mathrm{m} / \mathrm{z}$ calculated for $\mathrm{C}_{34} \mathrm{H}_{58} \mathrm{O}_{10} \mathrm{NaSi}_{2}[\mathrm{M}+\mathrm{Na}]+705 \cdot 3466$, found $705 \cdot 3466$.

4.1.24. 1-((2R,3S)-4-hydroxy-3-methylbutan-2-yl) 4-methyl 3-((2-(trimethylsilyl)ethoxy)methyl) $\quad(R, Z)-2-(($ tertbutyldimethylsilyl)oxy)pent-3-ene-1,3,4-tricarboxylate and $1-((2 R, 3 S)-4$-hydroxy-3-methylbutan-2-yl) 3-methyl 4-((2-(trimethylsilyl)ethoxy)methyl) $\quad(R, Z)-2-(($ tertbutyldimethylsilyl)oxy)pent-3-ene-1,3,4-tricarboxylate (42): DDQ (84.0 $\mathrm{mg}, 0.37 \mathrm{mmol}$ ) was added to a solution of $41(126 \mathrm{mg}, 0.18 \mathrm{mmol})$ in $\mathrm{CH}_{2} \mathrm{Cl}_{2}(1.60 \mathrm{~mL})$ and phosphate buffer $\mathrm{pH} 7.0(0.18 \mathrm{~mL})$ at o ${ }^{\circ} \mathrm{C}$. The reaction was stirred for 4 $\mathrm{h}$, and then quenched by the addition of a saturated aqueous solution of $\mathrm{NaHCO}_{3}(2.00 \mathrm{~mL})$. The mixture was filtered through a plug of Celite ${ }^{\circledR}$ and eluted with $\mathrm{CH}_{2} \mathrm{Cl}_{2}$. The crude material obtained was purified by flash chromatography, eluted with hexane:AcOEt 3:1 to provide $88.0 \mathrm{mg}$ of alcohol $\mathbf{4 2}, 85 \%$ yield.

Rf $=0.3$ (hexane:AcOEt: 70:30). $[\alpha]_{\mathrm{D}}^{25}=+\mathbf{2 . 0}\left(\mathrm{c} \mathrm{o.7}, \mathrm{CHCl}_{3}\right) .{ }^{\mathbf{1}} \mathbf{H}$ NMR (50o MHz, $\mathbf{C D C l}_{3}$ ) $\delta_{5.44-5.19}(\mathrm{~m}, \mathbf{2 H}), 5.18$ (dd, $J$ 8.3, 5.o Hz, $1 \mathrm{H}), 4.97-4.91(\mathrm{~m}, 1 \mathrm{H}), 3.81-3.71(\mathrm{~m}, 2 \mathrm{H}), 3.77\left(\mathrm{~s},{ }_{3} \mathrm{H}\right)$, 3.54 (qd, J 11.2, 4.6 Hz, $2 \mathrm{H}$ ), 2.95 (dd, J = 15.6, 8.4 Hz, $1 \mathrm{H}$ ), 2.73 (dd, $J 15.7,4.9 \mathrm{~Hz}, 1 \mathrm{H}), 2.06(\mathrm{~s}, 3 \mathrm{H}), 1.82-1.77(\mathrm{~m}, 1 \mathrm{H}), 1.25(\mathrm{~d}, J$ $6.4 \mathrm{~Hz}, 3 \mathrm{H}), 1.02-0.97(\mathrm{~m}, 5 \mathrm{H}), 0.87(\mathrm{~s}, 9 \mathrm{H})$, $0.11\left(\mathrm{~s},{ }_{3} \mathrm{H}\right), 0.08$ $\left(\mathrm{s},{ }_{3} \mathrm{H}\right)$, $0.05(\mathrm{~s}, 9 \mathrm{H}) .{ }^{13} \mathbf{C}\left\{{ }^{1} \mathbf{H}\right\}$ NMR major regioisomer $(125$ $\left.\mathrm{MHz}, \mathrm{CDCl}_{3}\right) \delta 170.9,168.3,166.9,141.7,130.8,90.2,72.6$, 68.2, 67.3, 64.2, 52.0, 42.0, 40.6, 25.6 (3C), 18.0, 17.9, 17.6, 15.0, 13.2, -1.4 (3C), -5.0, -5.3. IR (film) 3486 (br), 3018, 2954, 2925, 2852, 1731, $1644 \mathrm{~cm}^{-1}$. HRMS (ESI+) $\mathrm{m} / \mathrm{z}$ calculated for

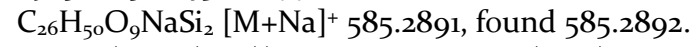

4.1.25. (2R,3S)-4-((4-Methoxylbenzyl)oxy)-3-methylbutan2-yl benzoate (43): $\mathrm{Bz}_{2} \mathrm{O}$ (1.09 g, $4.81 \mathrm{mmol}$ ), DIPEA (1.12 $\mathrm{mL}, 6.42 \mathrm{mmol}$ ) and DMAP (39.2 $\mathrm{mg}, 0.32 \mathrm{mmol})$ were added to a solution of 12 (360 $\mathrm{mg}, 1.61 \mathrm{mmol})$ in $\mathrm{CH}_{2} \mathrm{Cl}_{2}(10.4 \mathrm{~mL})$. The reaction was stirred for $18 \mathrm{~h}$, after which ethylenediamine $(1.80 \mathrm{~mL})$ and $\mathrm{H}_{2} \mathrm{O}(5.00 \mathrm{~mL})$ were added. The layers were separated, and the aqueous one was extracted with $\mathrm{CH}_{2} \mathrm{Cl}_{2}(2 \times 15.0 \mathrm{~mL})$ and $\mathrm{Et}_{2} \mathrm{O}(15.0 \mathrm{~mL})$. The combined organic layers were dried over $\mathrm{MgSO}_{4}$, filtrated and concen- 
trated under reduced pressure. The crude material was purified by flash chromatography, eluted with hexane:AcOEt $80: 20$ to provide $485 \mathrm{mg}$ of $43,92 \%$ yield.

$\mathbf{R f}=0.53$ (hexane:AcOEt 8o:20). $[\alpha]_{\mathrm{D}}=-32.0\left(\right.$ c 1.4, $\left.\mathrm{CHCl}_{3}\right) .{ }^{\mathbf{1}} \mathbf{H}$ NMR (250 MHz, $\left.\mathbf{C D C l}_{3}\right) \delta 8.03(\mathrm{~d}, J 7.3 \mathrm{~Hz}, 2 \mathrm{H}), 7.55(\mathrm{t}, J 7.3$ $\mathrm{Hz}, 1 \mathrm{H}), 7.43(\mathrm{t}, J 7.5 \mathrm{~Hz}, 2 \mathrm{H}), 7.25$ (d, J 8.5 Hz, 2H), 6.85 (d, J $8.5 \mathrm{~Hz}, 2 \mathrm{H}$ ), 5.23 (quint, $J 6.3 \mathrm{~Hz}, 1 \mathrm{H}), 4.44(\mathrm{~s}, 2 \mathrm{H}), 3.78(\mathrm{~s}$, $3 \mathrm{H}), 3.52(\mathrm{dd}, J$ 9.2, $5.7 \mathrm{~Hz}, 1 \mathrm{H}), 3.40\left(\mathrm{dd}, J\right.$ 9.2, $\left.6.4 \mathrm{~Hz},{ }_{1} \mathrm{H}\right)$, $2.20(\mathrm{dt}, J 12.9,6.5 \mathrm{~Hz}, 1 \mathrm{H}), 1.33\left(\mathrm{~d}, J 6.4 \mathrm{~Hz},{ }_{3} \mathrm{H}\right), 1.06(\mathrm{~d}, J 6.9$ $\left.\mathrm{Hz},{ }_{3} \mathrm{H}\right) .{ }^{13} \mathbf{C}\left\{{ }^{1} \mathbf{H}\right\}$ NMR (62.5 $\left.\mathbf{M H z}, \mathbf{C D C l}_{3}\right) \delta 165.7,158.9,132.5$ (2C), 130.6, 130.3, 129.3 (2C), 129.0, 128.1 (2C), 113.5 (2C), 72.5, 72.5, 71.5, 55.0, 38.1, 16.5, 12.9. IR (ATR) 3063, 3033, 2972, 2935, 2855, 1712, $1613 \mathrm{~cm}^{-1}$. HRMS (ESI+) $\mathrm{m} / \mathrm{z}$ calculated for $\mathrm{C}_{20} \mathrm{H}_{24} \mathrm{O}_{4} \mathrm{Na}[\mathrm{M}+\mathrm{Na}]^{+}$351.1572, found 351.1564.

4.1.26. $\quad(2 R, 3 S)-4$-Hydroxy-3-methylbutan-2-yl benzoate (44): DDQ (522 mg, $2.30 \mathrm{mmol}$ ) was added to a solution of 43 (464 mg, $1.41 \mathrm{mmol}$ ) in $\mathrm{CH}_{2} \mathrm{Cl}_{2}(13.8 \mathrm{~mL}$ ) and phosphate buffer $\mathrm{pH} 7.0(1.53 \mathrm{~mL})$ at $\mathrm{o}{ }^{\circ} \mathrm{C}$. The reaction was stirred for $3.5 \mathrm{~h}$, and then quenched by the addition of a saturated aqueous solution of $\mathrm{NaHCO}_{3}(7.90 \mathrm{~mL})$. The mixture was filtered through a plug of Celite ${ }^{\circledast}$ and eluted with $\mathrm{CH}_{2} \mathrm{Cl}_{2}$. The crude material was purified by flash chromatography, eluted with hexane:AcOEt 70:30 to provide $250 \mathrm{mg}$ of $\mathbf{4 4}, 83 \%$ yield.

$\mathbf{R f}=0.32$ (hexane:AcOEt 70:30). $[\alpha]_{\mathrm{D}}^{25}=-22.0\left(\right.$ c o.8, $\left.\mathrm{CHCl}_{3}\right)$. 'H NMR (250 MHz, $\left.\mathbf{C D C l}_{3}\right) \delta 8.04(\mathrm{~d}, J 7.1 \mathrm{~Hz}, 2 \mathrm{H}), 7.57(\mathrm{t}, J$ $7.4 \mathrm{~Hz}, 1 \mathrm{H}), 7.45(\mathrm{t}, J 7.4 \mathrm{~Hz}, 2 \mathrm{H}), 5.27-5.12\left(\mathrm{~m},{ }_{1} \mathrm{H}\right), 3.61(\mathrm{~d}, J$ $4.7 \mathrm{~Hz}, 2 \mathrm{H}), 2.04-1.90(\mathrm{~m}, 1 \mathrm{H}), 1.62(\mathrm{sl}, 1 \mathrm{H}), 1.37(\mathrm{~d}, J 6.4 \mathrm{~Hz}$, $3 \mathrm{H}), 1.07(\mathrm{~d}, J$ 7.0 Hz, $3 \mathrm{H}) .{ }^{13} \mathbf{C}\left\{{ }^{1} \mathbf{H}\right\}$ NMR (62.5 $\left.\mathbf{M H z}, \mathbf{C D C l}_{3}\right) \delta$ 166.6, 133.0, 130.4, 129.6 (2C), 128.4 (2C), 72.8, 64.3, 40.8, 17.5, 13.2. IR (ATR) 3437 (br), 2978, 2935, 2882, 1715, 1698, 1602, $1585 \mathrm{~cm}^{-1}$. HRMS (ESI+) $\mathrm{m} / \mathrm{z}$ calculated for $\mathrm{C}_{12} \mathrm{H}_{16} \mathrm{O}_{3} \mathrm{Na}$ $[\mathrm{M}+\mathrm{Na}]^{+}$231.0997, found 231.0991.

4.1.27. (2R,3R)-3-Methyl-4-oxobutan-2-yl benzoate (45): Oxalyl chloride $(68.0 \mu \mathrm{L}, 0.78 \mathrm{mmol})$ was added dropwise to a solution of DMSO (74.0 $\mu \mathrm{L}, 1.04 \mathrm{mmol})$ in $\mathrm{CH}_{2} \mathrm{Cl}_{2}(4.00 \mathrm{~mL})$ at $-78{ }^{\circ} \mathrm{C}$. The mixture was stirred for 15 minutes. Thus, a solution of $44(108 \mathrm{mg}, 0.52 \mathrm{mmol})$ in $\mathrm{CH}_{2} \mathrm{Cl}_{2}(2.00 \mathrm{~mL})$ was slowly added. The reaction was stirred for $1 \mathrm{~h}$ and $\mathrm{Et}_{3} \mathrm{~N}$ (o.29 $\mathrm{mL}, 2.07 \mathrm{mmol}$ ) was added dropwise. The reaction was allowed to warm up to o ${ }^{\circ} \mathrm{C}$. After reaching this temperature, quench by addition of a saturated aqueous solution of $\mathrm{Na}$ $\mathrm{HCO}_{3}$ (10.0 mL) was performed. The mixture was extracted with $\mathrm{CH}_{2} \mathrm{Cl}_{2}(2 \times 20.0 \mathrm{~mL})$. The combined organic layers were filtered through silica gel and eluted with hexane:AcOEt 8o:20. The crude aldehyde $\mathbf{4 5}$ obtained was used in the next step without further purification.

4.1.28. (But-1-en-2-yloxy)trimethylsilane (13):43 nBuLi (72.1 $\mathrm{mL}, 180 \mathrm{~mL} \mathrm{mmol}$ ) was slowly added to a solution of DIPA (29.6 mL, $208 \mathrm{mmol})$ in THF $(154 \mathrm{~mL})$ at o ${ }^{\circ} \mathrm{C}$. After which the mixture was cooled down to $-78^{\circ} \mathrm{C}$ and $\mathrm{TMSCl}(35.5 \mathrm{~mL}$, $277 \mathrm{mmol}$ ) was added. Thus, butanone (12.4 mL, $139 \mathrm{mmol})$ was added to the reaction and the mixture was stirred for 15 minutes. After, $\mathrm{Et}_{3} \mathrm{~N}$ (38.7 mL, $277 \mathrm{mmol}$ ) was added and the reaction was stirred for additional 30 minutes. The reaction was warmed up to room temperature and quenched by the addition of a saturated aqueous solution of $\mathrm{NaHCO}_{3}$ (20.0 $\mathrm{mL}$ ). The layers were separated, and the aqueous one was extracted with pentane $(3 \times 60.0 \mathrm{~mL})$. The combined organic layers were washed with a saturated aqueous solution of $\mathrm{CuSO}_{4}(2 \times 30.0 \mathrm{~mL})$ and concentrated through vigreux column distillation $(20.0 \mathrm{~cm})$. The crude material was purified by distillation under reduced pressure to provide $8.30 \mathrm{~g}$ of $\mathbf{1 3}$, $41 \%$ yield.

'H NMR (250 MHz, $\left.\mathbf{C D C l}_{3}\right) \delta 4.04(\mathrm{~d}, J 3.9 \mathrm{~Hz}, 2 \mathrm{H}), 2.01$ (q, $J$ 8.o Hz, $2 \mathrm{H})$, $1.03(\mathrm{t}, J 8.0 \mathrm{~Hz}, 3 \mathrm{H}), 0.2(\mathrm{~s}, 9 \mathrm{H})$.

4.1.29. $\quad(2 R, 3 S, 4 R)-4$-Hydroxy-3-methyl-6-oxooctan-2-yl benzoate (47): $\mathrm{BF}_{3} \cdot \mathrm{OEt}_{2}(72.0 \mu \mathrm{L}, 0.57 \mathrm{mmol})$ was slowly added to a solution of the crude aldehyde 45 and enol silyl ether derivative 13 (0.14 mL, $0.78 \mathrm{mmol})$ in $\mathrm{CH}_{2} \mathrm{Cl}_{2}(6.50 \mathrm{~mL})$ at $-78^{\circ} \mathrm{C}$. The reaction was stirred for $1 \mathrm{~h}$ and then quenched by addition of a saturated aqueous solution of $\mathrm{NaHCO}_{3}(8.00$ $\mathrm{mL}$ ). The layers were separated, and the aqueous layer was extracted with $\mathrm{CH}_{2} \mathrm{Cl}_{2}$ (3 $\times 8.00 \mathrm{~mL}$ ). The combined organic layers were dried over $\mathrm{MgSO}_{4}$, filtrated and concentrated under reduced pressure. The crude material was purified by flash chromatography, eluted with hexane:AcOEt 70:30 to provide $60.0 \mathrm{mg}$ of 47 (d.r. $4: 1$ ), $42 \%$ yield.

$\mathbf{R f}=0.37$ (hexane:AcOEt 70:30). $[\alpha]_{\mathrm{D}}^{25}=-15.0\left(c\right.$ 1.0, $\left.\mathrm{CHCl}_{3}\right)$. ${ }^{1} \mathbf{H}$ NMR (50o $\mathbf{~ M H z}, \mathbf{C D C l}_{3}$ ) major diastereomer $\delta 8.06$ (dd, $J$ 7.2, 6.o Hz, 2H), $7.59(\mathrm{t}, J 7.4 \mathrm{~Hz}, 1 \mathrm{H}), 7.47(\mathrm{t}, J 7.7 \mathrm{~Hz}, 2 \mathrm{H})$, $5.22(\mathrm{dq}, J 13.0,6.4 \mathrm{~Hz}, 1 \mathrm{H}), 4.28(\mathrm{dt}, J$ 9.4, 3.0 Hz, $1 \mathrm{H}), 3.06$ (s, $1 \mathrm{H}), 2.74(\mathrm{dd}, J 16.9,9.4 \mathrm{~Hz}, 1 \mathrm{H}), 2.51-2.47\left(\mathrm{~m},{ }_{3} \mathrm{H}\right), 1.84-1.76$ $(\mathrm{m}, 1 \mathrm{H}), 1.40(\mathrm{~d}, J 6.4 \mathrm{~Hz}, 3 \mathrm{H}), 1.07\left(\mathrm{t}, J 7.1 \mathrm{~Hz},{ }_{3} \mathrm{H}\right), 1.03(\mathrm{~d}, J$ 7.0 $\left.\mathrm{Hz},{ }_{3} \mathrm{H}\right) .{ }^{13} \mathbf{C}\left\{{ }^{1} \mathbf{H}\right)$ NMR (125 $\left.\mathbf{M H z}, \mathbf{C D C l}_{3}\right)$ major diastereomer $\delta 211.6,166.5,133.0,130.6,129.6\left({ }_{2} \mathrm{C}\right), 128.3(2 \mathrm{C})$, 73.0, 66.5, 46.7, 42.9, 36.8, 17.8, 9.3, 7.5. IR (film) 3505, 2979, 2938, 1713, 1602, $1585 \mathrm{~cm}^{-1}$. HRMS (ESI+) $\mathrm{m} / \mathrm{z}$ calculated for $\mathrm{C}_{16} \mathrm{H}_{22} \mathrm{O}_{4} \mathrm{Na}[\mathrm{M}+\mathrm{Na}]^{+}$301.1416, found 301.1409.

4.1.30. $\left(2 S,{ }_{4} R,{ }_{5} S, 6 R\right)$-2-Ethyl-2-methoxy-5,6-dimethyltetra hydro-2H-pyran-4-ol (48): $\mathrm{Ba}(\mathrm{OH})_{2} \cdot 8 \mathrm{H}_{2} \mathrm{O} \quad(431 \mathrm{mg}, 1.36$ $\mathrm{mmol}$ ) was added to a solution of $47(38.0 \mathrm{mg}, 0.14 \mathrm{mmol})$ in $\mathrm{MeOH}(19.5 \mathrm{~mL})$ at room temperature. The reaction was stirred for 30 minutes. Thus, the mixture was filtered through silica gel and eluted with pure AcOEt to provide 14.0 mg of $48,55 \%$ yield.

Rf $=0.45$ (hexane:AcOEt 70:30). $[\alpha]_{\mathrm{D}}^{25}=-3.0\left(\right.$ ( $\left.0.3, \mathrm{CHCl}_{3}\right)$. ${ }^{1} \mathrm{H}$ NMR $\left(500 \mathrm{MHz}, \mathrm{CDCl}_{3}\right) \delta_{3.68}(\mathrm{dq}, J 10.1,6.3 \mathrm{~Hz}, 1 \mathrm{H}), 3.37$ $(\mathrm{s}, 3 \mathrm{H}), 3.28-3.20(\mathrm{~m}, 1 \mathrm{H}), 2.23(\mathrm{dd}, J 12.5,4.7 \mathrm{~Hz}, 1 \mathrm{H}), 1.82(\mathrm{~s}$, $1 \mathrm{H}), 1.66$ (qd, J 7.5, $2.7 \mathrm{~Hz}, 2 \mathrm{H}), 1.27-1.22(\mathrm{~m}, 2 \mathrm{H}), 1.18$ (d, J 6.3 $\mathrm{Hz}, 3 \mathrm{H}), 0.97$ (d, J $6.5 \mathrm{~Hz}, 3 \mathrm{H}), 0.99\left(\mathrm{t}, J 7.6 \mathrm{~Hz},{ }_{3} \mathrm{H}\right) .{ }^{13} \mathbf{C}\left\{{ }^{1} \mathbf{H}\right\}$ NMR (125 MHz, CDCl3) $\delta$ 98.4, 79.0, 70.5, 56.5, 43.7, 37.0, 36.1, 19.3, 13.0, 7.5. IR (film) 3590, 3412, 3012, 3005, 2971, 2929, $2851 \mathrm{~cm}^{-1}$. HRMS (ESI+) $\mathrm{m} / \mathrm{z}$ calculated for $\mathrm{C}_{10} \mathrm{H}_{20} \mathrm{O}_{3} \mathrm{Na}$ $[\mathrm{M}+\mathrm{Na}]^{+}$211.1310, found 211.1305.

4.1.31. 1- $((2 R, 3 S, 4 R)-4-H y d r o x y-3-m e t h y l-6-o x o o c t a n-2-y l)$ 3-methyl 4-((2-(trimethylsilyl)ethoxy)methyl) (R,Z)-2((tert-butyldimethylsilyl)oxy)pent-3-ene-1,3,4-tricarboxy late and $1-((2 R, 3 S, 4 R)-4$-hydroxy-3-methyl-6-oxooctan-2yl) 4-methyl 3-((2-(trimethylsilyl)ethoxy)methyl) $(R, Z)$ 2-((tert-butyldimethylsilyl)oxy)pent-3-ene-1,3,4-tricarbo xylate (50)

4.1.31.a. Oxalyl chloride $(84.0 \mu \mathrm{L}, 0.97 \mathrm{mmol})$ was slowly added to a solution of DMSO $(80.0 \mu \mathrm{L}, 1.13 \mathrm{mmol})$ in $\mathrm{CH}_{2} \mathrm{Cl}_{2}$ (2.00 $\mathrm{mL}$ ) at $-78{ }^{\circ} \mathrm{C}$. The mixture was stirred for 15 minutes and a solution of alcohol $42(181 \mathrm{mg}, 0.32 \mathrm{mmol})$ in $\mathrm{CH}_{2} \mathrm{Cl}_{2}$ $(1.20 \mathrm{~mL})$ was added dropwise. The reaction was stirred for 1 $\mathrm{h}$ and then $\mathrm{Et}_{3} \mathrm{~N}$ (0.27 mL, $1.93 \mathrm{mmol}$ ) was added dropwise. The reaction was allowed to warm up to $\mathrm{o}{ }^{\circ} \mathrm{C}$ and thus quenched by the addition of a saturated aqueous solution of $\mathrm{NaHCO}_{3}(5.00 \mathrm{~mL})$. The mixture was extracted with $\mathrm{CH}_{2} \mathrm{Cl}_{2}$ $(2 \times 10.0 \mathrm{~mL})$. The combined organic layers were filtered through silica gel and eluted with hexane:AcOEt 80:20. The 
crude aldehyde 49 obtained was used in the next step without further purification.

4.1.31.b. $\mathrm{BF}_{3} \cdot \mathrm{OEt}_{2}$ (30.0 $\mu \mathrm{L}, 0.25 \mathrm{mmol}$ ), was slowly added to a solution of the aldehyde previously synthesized and enol silyl ether derivative $13(86.0 \mu \mathrm{L}, 0.47 \mathrm{mmol})$ in $\mathrm{CH}_{2} \mathrm{Cl}_{2}(2.79 \mathrm{~mL})$ at $-78{ }^{\circ} \mathrm{C}$. The reaction was stirred for $1 \mathrm{~h}$ and then it was quenched by the addition of a saturated aqueous solution of $\mathrm{NaHCO}_{3}(8.00 \mathrm{~mL})$. The layers were separated, and the aqueous layer was extracted with $\mathrm{CH}_{2} \mathrm{Cl}_{2}(3 \times 8.00 \mathrm{~mL})$. The combined organic layers were dried over $\mathrm{MgSO}_{4}$, filtrated and concentrated under reduced pressure. The crude material was purified by flash chromatography, eluted with hexane:AcOEt 75:25 to provide $102 \mathrm{mg}$ of intermediate $50,50 \%$ yield (2 steps).

$\mathbf{R f}=0.29$ (hexane:AcOEt 70:30). $[\alpha]_{\mathrm{D}}^{25}=+9.0\left(\right.$ c o.8, $\left.\mathrm{CHCl}_{3}\right)$. 'H NMR (50o $\mathbf{M H z}, \mathbf{C D C l}_{3}$ ) major diastereomer $\delta 5.39-5.32$ $(\mathrm{m}, 2 \mathrm{H}), 5.17(\mathrm{dd}, J 8.7,4.3 \mathrm{~Hz}, 1 \mathrm{H}), 5.01-4.89(\mathrm{~m}, 1 \mathrm{H}), 4.20$ (dd, J 6.7, 2.7 Hz, $1 \mathrm{H}$ ), 3.81- $3.70\left(\mathrm{~m},{ }_{5} \mathrm{H}\right), 2.98$ (dd, J 15.8, 8.7 $\mathrm{Hz}, 2 \mathrm{H}), 2.72-2.64(\mathrm{~m}, 2 \mathrm{H}), 2.49(\mathrm{q}, J 7.2 \mathrm{~Hz}, 3 \mathrm{H}), 2.05(\mathrm{~s}$, $3 \mathrm{H}), 1.68-1.58(\mathrm{~m}, 1 \mathrm{H}), 1.28-1.23(\mathrm{~m}, 3 \mathrm{H}), 1.07(\mathrm{t}, J 7.3 \mathrm{~Hz}$, $3 \mathrm{H}), 0.97(\mathrm{dd}, J 20.8,12.6 \mathrm{~Hz}, 4 \mathrm{H}), 0.86(\mathrm{~d}, J 6.6 \mathrm{~Hz}, 9 \mathrm{H}), 0.10$ $(\mathrm{s}, 3 \mathrm{H})$, $0.06(\mathrm{~s}, 3 \mathrm{H}), 0.04(\mathrm{~s}, 9 \mathrm{H}),{ }^{13} \mathbf{C}\left\{{ }^{1} \mathrm{H}\right\}$ NMR $(125 \mathrm{MHz}$, $\mathrm{CDCl}_{3}$ ) major diastereomer $\delta 211.7,170.7,168.2,166.9,141.8$, 127.6, 90.2, 72.8, 68.1, 67.3, 66.2, 52.3, 46.8, 42.6, 42.0, 36.8, $25.6\left({ }_{3} C\right)$, 18.0, 18.0, 17.9, 14.9, 9.1, 7.5, -1.4 ( $\left.{ }_{3} \mathrm{C}\right),-4.9,-5.4$. IR (film) 3528, 2954, 2930, 2858, 1732, $1644 \mathrm{~cm}^{-1}$. HRMS (ESI+) $\mathrm{m} / \mathrm{z}$ calculated for $\mathrm{C}_{30} \mathrm{H}_{56} \mathrm{O}_{10} \mathrm{NaSi}_{2}[\mathrm{M}+\mathrm{Na}]+655 \cdot 3310$, found 655.3310 .

4.1.32. 4-Methyl 1- $((2 R, 3 R, 4 R)-3-m e t h y l-6-0 x 0-4-$ ((trimethylsilyl)oxy)octan-2-yl) 3-((2-(trimethylsilyl) ethoxy)methyl) (R,Z)-2-((tert-butyldimethylsilyl)oxy) pent-3-ene-1,3,4-tricarboxylate and 3-methyl 1$((2 R, 3 R, 4 R)$-3-methyl-6-oxo-4-((trimethylsilyl)oxy)octan2-yl) 4-((2-(trimethylsilyl)ethoxy)methyl) $(R, Z)-2-(($ tert butyldimethylsilyl)oxy)pent-3-ene-1,3,4-tricarboxylate

(Fragment C13-C25): TMS-imidazole (6o.o $\mu \mathrm{L}, 0.41 \mathrm{mmol}$ ) was added to a solution of $\mathbf{5 0}\left(26.0 \mathrm{mg}\right.$, $0.04 \mathrm{mmol}$ ) in $\mathrm{CH}_{2} \mathrm{Cl}_{2}$ (o.40 mL) at room temperature. The reaction was stirred for $2 \mathrm{~h}$ and then filtered through silica gel and eluted with hexane:AcOEt 90:10 to provide $29.0 \mathrm{mg}$ of the $\mathrm{C}_{13}-\mathrm{C}_{25}$ fragment, $100 \%$ yield.

$\mathbf{R f}=0.26$ (hexane:AcOEt 90:10). $[\alpha]_{\mathrm{D}}^{25}=+6.0\left(\right.$ ( $\left.0.5, \mathrm{CHCl}_{3}\right)$. ${ }^{1} \mathbf{H}$ NMR (50o $\mathbf{M H z}, \mathbf{C D C l}_{3}$ ) major diastereomer $\delta 5.40-5.33$ (m, 2H), $5.19(\mathrm{dd}, J$ 9.2, 3.1 Hz, $1 \mathrm{H}), 4.82-4.75(\mathrm{~m}, 1 \mathrm{H}), 4.39-$ $4.33(\mathrm{~m}, 1 \mathrm{H}), 3.81-3.72(\mathrm{~m}, 5 \mathrm{H}), 3.02(\mathrm{dd}, J 16.3,9.2 \mathrm{~Hz}, 1 \mathrm{H})$, $2.70(\mathrm{dd}, J 16.1,7.6 \mathrm{~Hz}, 1 \mathrm{H}), 2.58(\mathrm{dd}, J 16.2,3.2 \mathrm{~Hz}, 1 \mathrm{H}), 2.51-$ $2.41(\mathrm{~m}, 3 \mathrm{H}), 2.05(\mathrm{~s}, 3 \mathrm{H}), 1.22(\mathrm{~d}, J 6.3 \mathrm{~Hz}, 3 \mathrm{H}), 1.08(\mathrm{t}, J 7.3$ $\mathrm{Hz}, 3 \mathrm{H}), 1.02-0.97(\mathrm{~m}, 2 \mathrm{H}), 0.91-0.85(\mathrm{~m}, 12 \mathrm{H}), 0.14-0.03$ $\left(\mathrm{m},{ }_{25} \mathrm{H}\right) . \quad{ }^{13} \mathrm{C}\left\{{ }^{1} \mathrm{H}\right\} \quad \mathrm{NMR} \quad\left(\mathbf{1 2 5} \mathbf{M H z}, \mathbf{C D C l}_{3}\right)$ major diastereomer $\delta$ 209.6, 170.5, 167.6, 167.0, 143.6, 128.9, 90.1, 72.6, 68.1, 68.0, 67.4, 51.9, 48.4, 43.3, 42.1, 37.3, 25.6 (3C), 18.0, 17.9, 17.5, 14.6, 9.5, 7.5, $0.2\left({ }_{3} \mathrm{C}\right),-1,4(3 \mathrm{C}),-5.0,-5.3$. IR (film) 2954, 2930, 2858, 1731, $1644 \mathrm{~cm}^{-1}$. HRMS (ESI+) $\mathrm{m} / \mathrm{z}$ calculated for $\mathrm{C}_{33} \mathrm{H}_{64} \mathrm{O}_{10} \mathrm{NaSi}_{3}[\mathrm{M}+\mathrm{Na}]^{+}$727.3705, found 727.3700.

\section{AUTHOR INFORMATION}

\section{Corresponding Author}

*E-mail: renata.marcia_de_figueiredo@enscm.fr

*E-mail: ldias@unicamp.br
*E-mail: jean-marc.campagne@enscm.fr

ORCID

Celso de Oliveira Rezende Júnior: oooo-00o3-1402-2035

Jean-Marc Campagne: oooo-ooo2-4943-047X

Luiz Carlos Dias: 0ooo-0003-0628-9928

Renata Marcia de Figueiredo: oooo-0oo1-5336-6071

Present Addresses

‡ (D.P.S.) Eurofarma - 3.565, Presidente Castelo Branco Highway - Itaqui, Itapevi - São Paulo, o6696-ooo, Brazil. (C.O.R.J.) Institute of Chemistry, Federal University of Uberlândia, 38400-902, Uberlândia, Minas Gerais, Brazil.

\section{Author Contributions}

All authors have given approval to the final version of the manuscript.

\section{Notes}

The authors declare no competing financial interest.

\section{ACKNOWLEDGMENT}

The authors are grateful to ENSCM, CNRS and UNICAMPCampinas/SP. We also thank the CAPES-FAPESP (PhD grant of D.P.S., project FAPESP 2012/11220-9) and CNPq-FAPESP for post-doctoral fellowship of C.O.R.J. (projects: FAPESP 14/50249-8 and 15/08541-6, CNPq 303154/2015-2, $573 \cdot 564 / 2008-6$ and $158926 / 2014-5)$.

\section{REFERENCES}

(1) Kobayashi, Y.; Ko, K.; Yamaguchi, I.; Shen, Y.-C.; Isono, K. A New Antibiotic, Tautomycetin. J. Antibiot. 1989, 42, 141-144.

(2) Cheng, X.-C.; Ubukata, M.; Isono, K. The Structure of Tautomycetin, a Dialkylmaleic Anhydride Antibiotic. J. Antibiot. 1990, 43, 890-896.

(3) Choi, S.-S.; Nah, H.-J.; Pyeon, H.-r.; Kim, E.-S. Biosynthesis, Regulation, and Engineering of a Linear Polyketide Tautomycetin: A Novel Immunosuppressant in Streptomyces sp. CK4412. J. Ind. Microbiol. Biotechnol. 2017, 44, 555-561.

(4) Osada, H.; Magae, J.; Watanabe, C.; Isono, K. Rapid Screening Method for Inhibitors of Protein. J. Antibiot. 1988, 41, 925931.

(5) Honkanen, R. E.; Golden, T. Regulators of Serine/Threonine Protein Phosphatases at the Dawn of a Clinical Era? Curr. Med. Chem. 2002, 9, 2055-2075.

(6) (a) Choy, M. S.; Swingle, M.; D’Arcy, B.; Abney, K.; Rusin, S. F.; Kettenbach, A. N.; Page, R.; Honkanen, R. E.; Peti, W. PP1: Tautomycetin Complex Reveals a Path toward the Developmentof PP1-Specific Inhibitors. J. Am. Chem. Soc. 2017, 139, 1770317706. (b) Mitsuhashi, S.; Matsuura, N.; Ubukata, M.; Oikawa, H.; Shima, H.; Kikuchi, K. Tautomycetin is a Novel and Specific Inhibitor of Serine/Threonine Protein Phosphatase Type 1, PP1. Biochem. Biophys. Res. Commun. 2001, 287, 328-331.

(7) Lee, J.-H.; Lee, J.-S.; Kim, S.-E.; Moon, B.-S.; Kim, Y.-C.; Lee, S.-K.; Lee, S.-K.; Choi, K.-Y. Tautomycetin Inhibits Growth of Colorectal Cancer Cells through p21cip/WAF1 Induction via the Extracellular Signal-Regulated Kinase Pathway. Mol. Cancer Ther. 2006, 5, 3222-3231.

(8) Niu, M.; Sun, Y.; Liu, X.; Tang, L.; Qiu, R. Tautomycetin Induces Apoptosis by Inactivating Akt Through a PP1Independent Signaling Pathway in Human Breast Cancer Cells. J. Pharmacol. Sci. 2013, 121, 17-24.

(9) Shim, J. H., Lee, H. K., Chang, E. J., Chae, W. J., Han, J. H., Han, D. J., Morio, T., Yang, J. J., Bothwell, A., Lee, S. K. Immunosuppressive Effects of Tautomycetin in vivo and in vitro via $\mathrm{T}$ 
Cell-Specific Apoptosis Induction. Proc. Natl. Acad. Sci. USA 2002, 99, 10617-10622.

(10) Han, D.J.; Jeong, Y.L.; Wee, Y.M.; Lee, A.Y.; Lee, H.K.; Ha, J.C.; Lee, S.K.; Kim, S.C. Tautomycetin as a Novel Immunosuppressant in Transplantation. Transplant. Proc. 2003, 35, 547-547. (11) Liu, S.; Yu, Z.; Yu, X.; Huang, S.-X.; Luo, Y.; Wu, L.; Shen, W.; Yang, Z.; Wang, L.; Gunawan, A. M.; Chan, R. J.; Shen, B.; Zhang, Z.-Y. SHP2 is a Target of the Immunosuppressant Tautomycetin. Chem. Biol. 2011, 18, 101-110.

(12) Dai, J.-P.; Sodeoka, M.; Shibasaki, M. Determination of the C-7,9,12,13,17 and 18 Stereochemistries of Tautomycetin. Synthesis of the Tautomycetin Degradation Product. Tetrahedron Lett. 1996, 37, 491-494.

(13) A similar behavior can be also observed in the case of tautomycin (5, Figure 1), a natural product that share the same dialkylmaleic anhydride moiety. (a) Oikawa, M.; Ueno, T.; Oikawa, H.; Ichihara, A. Total Synthesis of Tautomycin. J. Org. Chem. 1995, 6o, 5048-5068. (b) Sheppeck II, J. E.; Liu, W.; Chamberlin A. R. Total Synthesis of the Serine/Threonine-Specific Protein Phosphatase Inhibitor Tautomycin. J. Org. Chem. 1997, 62, 387-398.

(14) Oikawa, H.; Yoneta, Y.; Ueno, T.; Oikawa, M.; Wakayama, T.; Ichihara, A. Synthetic Study of Tautomycetin: Synthesis of Two Large Subunits. Tetrahedron Lett. 1997, 38, 7897-7900.

(15) Oikawa, H. Synthesis of Specific Protein Phosphatase Inhibitors, Tautomycin and Tautomycetin toward Structure-Activity Relationship Study. Curr. Med. Chem. 2002, 9, 2033-2054.

(16) Trost, B. M.; Sorum, M. T.; Chan, C.; Harms, A. E.; Rühter, G. Palladium-Catalyzed Additions of Terminal Alkynes to Acceptor Alkynes. J. Am. Chem. Soc. 1997, 119, 698-708.

(17) Suppo, J.-S.; de Sant'Ana, D. P.; Dias, L.-C.; de Figueiredo, R. M.; Campagne, J.-M. Efficient and Practical Procedure for the Esterification of the Free $\alpha$-Carboxylic Acid of Amino Acid Residues with $\beta$-(Trimethylsilyl)ethoxymethyl Chloride and Triisopropylsilyl Chloride. Synthesis 2014, 46, 3075-3084.

(18) (a) Zhu, G.; Liang, B.; Negishi, E.-i. Efficient and Selective Synthesis of $(S, R, R, S, R, S)-4,6,8,10,16,18$-Hexamethyldocosane via Zr-Catalyzed Asymmetric Carboalumination of Alkenes (ZACA Reaction). Org. Lett. 20o8, 10, 1099-1101. (b) Kondakov, D. Y.; Negishi, E.-i. Zirconium-Catalyzed Enantioselective Methylalumination of Monosubstituted Alkenes. J. Am. Chem. Soc. 1995, 117, 10771-10772. (c) Negishi, E.-i. Discovery of ZACA Reaction: $\mathrm{Zr}$-Catalyzed Asymmetric Carboalumination of Alkenes. ARKIVOC 2011, (viii), 34-53.

(19) Katsuki, T.; Sharpless, K. B. The First Practical Method for Asymmetric Epoxidation. J. Am. Chem. Soc. 1980, 102, 5974-5976. (20) Roush, W. R.; Adam, M. A.; Peseckis, S. M. Regioselectivity of the Reactions of Trialkylaluminum Reagents with 2,3Epoxyalcohols: Application to the Synthesis of $\alpha$-Chiral Aldehydes. Tetrahedron Lett. 1983, 24, 1377-1380.

(21) The ${ }^{13} \mathrm{C}$ and ${ }^{1} \mathrm{H}$ NMR spectra are in agreement with the ones described by Negishi and co-workers, see ref. 18a.

(22) It should be noted that even though this route is slightly longer (two additional steps compared to the one devised by Negishi, see scheme 2), the reactions in this case are straightforward and scalable allowing us to make grams of this key intermediate.

(23) (a) Garegg, P.J. Some Apects of Regio-, Stereo- and Chemoselective Reactions in Carbohydrate Chemistry. Pure and Appl. Chem. 1984, 56, 845-858. (b) Garegg, P.J.; Samuelsson, B. Novel Reagent System for Converting a Hydroxy-Group into an Iodo-Group in Carbohydrates with Inversion of Configuration. Part 2. J. Chem. Soc., Perkin Trans. 1 1980, 2866-2869.

(24) (a) Balasubramaniam, S.; Aidhen, I. S. The Growing Synthetic Utility of the Weinreb Amide. Synthesis 2oo8, 23, 3707-3738. (b) Nowak, M. Weinreb Amides. Synthesis 2015, 26, 561-562. (c) Kalepu, J.; Pilarski L. T. Weinreb Amides as Directing Groups for
Transition Metal-Catalyzed C-H Functionalizations. Molecules 2019, DOI:10.3390/molecules24050830.

(25) Triene 19 showed to be unstable and was used as soon as possible for the oxidative cleavage step.

(26) It might be mentioned, that segment $\mathrm{C}_{1}-\mathrm{C}_{12}$ supporting the aldehyde function could be synthesized in gram scale and also purified by flash chromatography. However, this key intermediate is not stable and might be used as soon as possible as extensive decomposition was observed under storage.

(27) (a) Ichikawa, Y.; Naganawan A.; Isobe, M. Synthesis of the 2,3-Disubstituted Maleic Anhydride Segment of Tautomycin. Synlett 1993, 1993(10), 737-738. (b) Ichikawa, Y.; Tsuboi, K.; Naganawan A.; Isobe, M. Synthesis of the (+)-2,3-Disubstituted Maleic Anhydride Segment and (+)-Enone Segment with C-25 through C-19 of Tautomycin. Synlett 1993, 1993(12), 907-908.

(28) (a) Yamamoto, Y.; Yatagai, H.; Maruyama, K. Stereocontrolled Cis Addition of Organocopper Reagents $\mathrm{RCu}^{*} \mathrm{BR}_{3} 3$ to $\alpha, \beta-$ Acetylenic Carbonyl Compounds. J. Org. Chem. 1979, 44, 17441746. (b) Marino, J. P.; Linderman, R. J. Chemistry of Substituted [ $\alpha$-(Carboethoxy)vinyl]cuprates and Their Synthetic Application to Cyclopentenone Annulations. J. Org. Chem. 1981, 46, 36963702. (c) Marino, J. P.; Linderman, R. J. Chemistry of Substituted $(\alpha$-Carbethoxyvinyl)cuprates. 2. Stereospecific Olefin Synthesis. J. Org. Chem. 1983, 48, 4621-4628.

(29) Corey, E. J.; Bakshi, R. K.; Shibata, S. Highly Enantioselective Borane Reduction of Ketones Catalyzed by Chiral Oxazaborolidines. Mechanism and Synthetic Implications. J. Am. Chem. Soc. 1987, 109, 5551-5553.

(30) The same trend on this enantioselective reduction step, with either CBS or (+)-DIP-Chloride methods, has been previously observed by the group of Chamberlin, see ref $13 \mathrm{~b}$ and Brown, H. C.; Ramachandran, V. Versatile $\alpha$-Pinene-Based Borane Reagents for Asymmetric Syntheses. J. Organomet. Chem. 1995, 500, 1-19.

(31) (a) Dale, J. A.; Mosher, H. S. Nuclear Magnetic Resonance Enantiomer Reagents. Configurational Correlations via Nuclear Magnetic Resonance Chemical Shifts of Diastereomeric Mandelate, O-Methylmandelate, and $\alpha$-methoxy- $\alpha$ trifluoromethylphenylacetate (MTPA) Esters. J. Am. Chem. Soc. 1973, 95, 512-519. (b) Seco, J. M.; Quiñoá, E.; Riguera, R. The Assignment of Absolute Configuration by NMR. Chem. Rev. 2004, 104, 17-118. (c) Hoye, T. R.; Jeffrey, C. S.; Shao, F. Mosher Ester Analysis for the Determination of Absolute Configuration of Stereogenic (Chiral) Carbinol Carbons. Nature Protocols 2007, 2, 2451-2458.

(32) Bal, B. S.; Childers, W. E.; Pinnick, H. W. Oxidation of $\alpha, \beta-$ unsaturated aldehydes. Tetrahedron 1981, 37, 2091-2096.

(33) Omura, K.; Swern, D. Oxidation of Alcohols by "Activated" Dimethyl Sulfoxide. A Preparative, Steric and Mechanistic Study. Tetrahedron 1978, 34, 1651-166o.

(34) (a) Gilman, H.; Jones, R. G.; Woods, L. A. The Preparation of Methylcopper and some Observations on the Decomposition of Organocopper Compounds. J. Org. Chem. 1952, 17, 1630-1634. (b) Normant, J. F. Organocopper(I) Compounds and Organocuprates in Synthesis. Synthesis 1972, 1972(2), 63-80.

(35) Tsuda, M.; Hatakeyama, A.; Kobayashi, J. Synthesis of a Diastereoisomer of the C-15 C-26 Segment of Amphidinolide L. J. Chem. Soc., Perkin Trans. 1 1980, 2866-2869.

(36) (a) Inanaga, J.; Hirata, K.; Saeki, H.; Katsuki, T.; Yamaguchi, M. A Rapid Esterification by Means of Mixed Anhydride and Its Application to Large-ring Lactonization. Bull. Chem. Soc. Jpn. 1979, 52, 1989-1993. (b) Kawanami, Y.; Dainobu, Y.; Inanaga, J.; Katsuki, T.; Yamaguchi, M. Synthesis of Thiol Esters by Carboxylic Trichlorobenzoic Anhydrides. Bull. Chem. Soc. Jpn. 1981, 54, 943-944. For a review, see: Yu, X.; Sun, D. Macrocyclic Drugs 
and Synthetic Methodologies toward Macrocycles. Molecules 2013, 6230-6268.

(37) (a) Evans, D. A.; Dart, M. J.; Duffy, J. L.; Yang, M. G. A Stereochemical Model for Merged 1,2- and 1,3-Asymmetric Induction in Diastereoselective Mukaiyama Aldol Addition Reactions and Related Processes. J. Am. Chem. Soc. 1996, 118, 4322-4343. (b) Evans, D. A.; Dart, M. J.; Duffy, J. L.; Yang, M. G.; Livingston, A. B. Diastereoselective Aldol and Allylstannane Addition Reactions. The Merged Stereochemical Impact of $\alpha$ and $\beta$ Aldehyde Substituents. J. Am. Chem. Soc. 1995, 117, 6619-6620. (c) Savall, B. M.; Blanchard, N.; Roush, W. R. Total Synthesis of the Formamicin Aglycon, Formamicinone. Org. Lett. 2003, 5, 377379 .

(38) (a) Evans, D. A.; Vogel, E.; Nelson, J. V. Stereoselective Aldol Condensations via Boron Enolates. J. Am. Chem. Soc. 1979, 101, 6120-6123. (b) Evans, D. A.; Nelson, J. V.; Vogel, E.; Taber, T. R. Stereoselective Aldol Condensations via Boron Enolates. J. Am. Chem. Soc. 1981, 103, 3099-3111. (c) Brown, H. C.; Bakshi, R. K.; Pandiarajan, P. K.; Singaram, B. Major Effect of the Leaving Group in Dialkylboron Chlorides and Triflates in Controlling the Stereospecific Conversion of Ketones into either $(E)$ - or (Z)-Enol Borinates. J. Am. Chem. Soc. 1989, 111, 3441-3442. (d) Brown, H. C.; Ganesan, K.; Dhar, R. K. Enolboration. 4. An Examination of the Effect of the Leaving Group (X) on the Stereoselective Enolboration of Ketones with Various R2BX/Triethylamine. New Reagents for the Selective Generation of either $Z$ or $E$ Enol
Borinates from Representative Ketones. J. Org. Chem. 1993, 58, 147-153. (e) Cowden, C. J.; Paterson, I. Asymmetric Aldol Reactions Using Boron Enolates. In Organic Reactions; John Wiley \& Sons, Inc., 1997, Vol. 51; p. 4.

(39) Dias, L. C.; Polo, E. C.; de Lucca Jr, E. C.; Ferreira, M. A. B. Asymmetric Induction in Aldol Additions. In Modern Methods inStereoselective Aldol Reactions; Mahrwald, R., Ed.; 1st ed.; Wiley-VCH: Weinheim, 2013, p. 293.

(40) The mass spectrum and HPLC profile are furnished on the Supporting Information. HPLC profile was compared to the one published in 2012 by Shen and co-workers, see: Yang, D.; Li, W.; Huang, S.-X.; Shen, B. Functional Characterization of ttnI Completing the Tailoring Steps for Tautomycetin Biosynthesis in Streptomyces griseochromogenes. Org. Lett. 2012, 14, 1302-1305.

(41) Landa, A.; Puente, Á.; Santos, J. I.; Vera, S.; Oiarbide, M.; Palomo, C. Catalytic Conjugate Additions of Geminal Bis(sulfone)s: Expanding the Chemistry of Sulfones as Simple Alkyl Anion Equivalents. Chem. Eur. J. 2009, 15, 11954-11962.

(42) Dias, L. C.; Polo, E. C. Nhatrangin A: Total Syntheses of the Proposed Structure and Six of Its Diastereoisomers. J. Org. Chem. 2017, 82, 4072-4112.

(43) Muratake, H.; Watanabe, M.; Goto, K.; Natsume, M. Synthesis of $( \pm)$ - and (-)-cis-Trikentrin A, ( \pm )- and (-)-transTrinkentrin A, $( \pm)$-cis-Trikentrin B, $( \pm)$-trans-Trikentrin B, and ( \pm )-iso-trans-Trikentrin B. Tetrahedron 1990, 46, 4179-4192. 